San Jose State University

SJSU ScholarWorks

Master's Theses

Master's Theses and Graduate Research

1993

\title{
A Profile of nonpoint source pollutants in the Palo Alto area and the feasibility of constructing wetlands as a treatment option
}

Mei Yee Wong

San Jose State University

Follow this and additional works at: https://scholarworks.sjsu.edu/etd_theses

\section{Recommended Citation}

Wong, Mei Yee, "A Profile of nonpoint source pollutants in the Palo Alto area and the feasibility of constructing wetlands as a treatment option" (1993). Master's Theses. 659.

DOI: https://doi.org/10.31979/etd.7te9-n4gy

https://scholarworks.sjsu.edu/etd_theses/659

This Thesis is brought to you for free and open access by the Master's Theses and Graduate Research at SJSU ScholarWorks. It has been accepted for inclusion in Master's Theses by an authorized administrator of SJSU ScholarWorks. For more information, please contact scholarworks@sjsu.edu. 


\section{INFORMATION TO USERS}

This manuscript has been reproduced from the microfilm master. UMI films the text directly from the original or copy submitted. Thus, some thesis and dissertation copies are in typewriter face, while others may be from any type of computer printer.

The quality of this reproduction is dependent upon the quality of the copy submitted. Broken or indistinct print, colored or poor quality illustrations and photographs, print bleedthrough, substandard margins, and improper alignment can adversely affect reproduction.

In the unlikely event that the author did not send UMI a complete manuscript and there are missing pages, these will be noted. Also, if unauthorized copyright material had to be removed, a note will indicate the deletion.

Oversize materials (e.g., maps, drawings, charts) are reproduced by sectioning the original, beginning at the upper left-hand corner and continuing from left to right in equal sections with small overlaps. Each original is also photographed in one exposure and is included in reduced form at the back of the book.

Photographs included in the original manuscript have been reproduced xerographically in this copy. Higher quality $6^{\prime \prime} \times 9^{\prime \prime}$ black and white photographic prints are available for any photographs or illustrations appearing in this copy for an additional charge. Contact UMI directly to order.

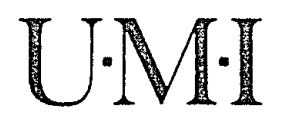

Universıly Microfilms International

A Bell \& Howell Informatıon Company 300 North Zeeb Road. Ann Arbor. MI 48106-1346 USA 

Order Number 1954174

A profile of nonpoint source pollutants in the Palo Alto area and the feasibility of constructing wetlands as a treatment option

\author{
Wong, Mei Yee, M.S. \\ San Jose State University, 1993
}

Copyright C1993 by Wong, Mei Yee. All rights reserved.

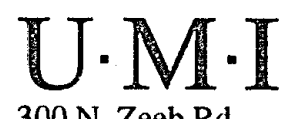

300 N. Zeeb Rd.

Ann Arbor, MI 48106 
$m$ 


\title{
A PROFILE OF NONPOINT SOURCE POLLUTANTS IN THE PAIO ALTO AREA AND THE FEASIBIIITY OF CONSTRUCTING WETLANDS AS A TREATMENT OPTION
}

\author{
A Thesis \\ Presented to \\ The Faculty of the Department of \\ Geography and Environmental Studies \\ San Jose State University \\ In Partial Fulfillment \\ of the Requirements for the Degree \\ Master of Science
}

by

Mei Yee Wong

August 1993 
APPROVED FOR THE DEPARTMENT OF GEOGRAPHY AND ENVIRONMENTAL STUDIES

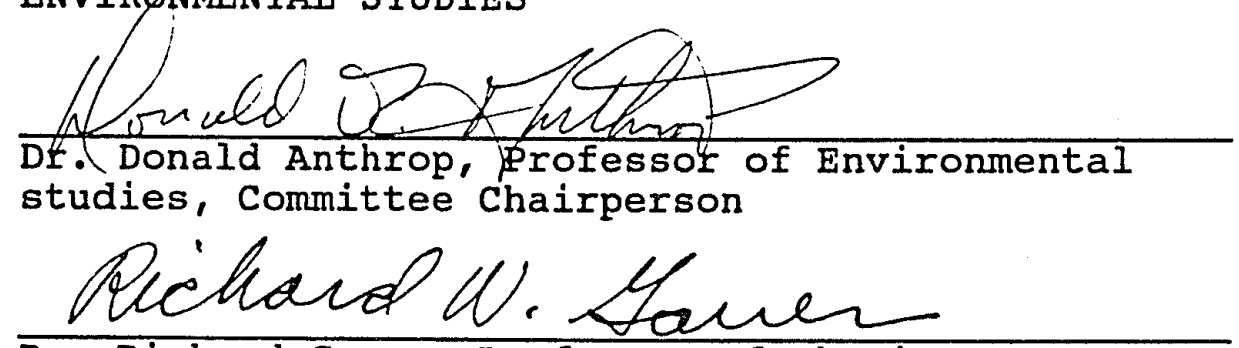

Dr. Richard aver, Professor of Chemistry

Riflebel

Mr. Phil Bobel, Manager of Environmental

Compliance Department, City of Plo Alto

APPROVED FOR THE UNIVERSITY

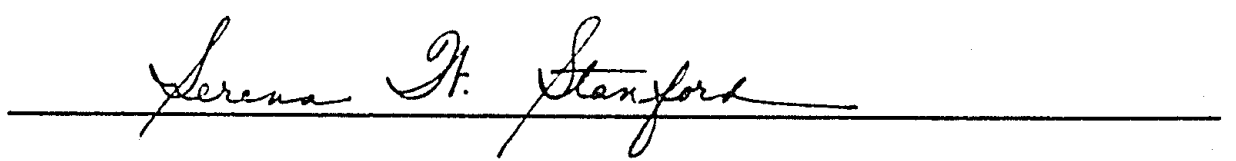




\section{ABSTRACT}

A PROFILE OF NONPOINT SOURCE POLLUTANTS IN THE PALO ALTO AREA AND THE FEASIBILITY OF CONSTRUCTING WETIANDS AS A TREATMENT OPTION

by Mei Yee Wong

Stormwater runoff from the Palo Alto area was sampled to determine a profile of pollutants from nonpoint source discharge using copper and lead concentrations as indicators. It was found that while the concentrations of both elements were quite high, the concentrations decreased by more than half after initial washoff.

In order to reduce the load releasing to the San Francisco Bay, it is feasible to construct fresh water wetlands to treat the runoff and to provide other advantages such as wildlife habitat enhancement and community amenities. 
To

\section{My Father}

who taught me how to dream

To

My Mother

who taught me how to make dreams come true 
TABLE OF CONTENTS

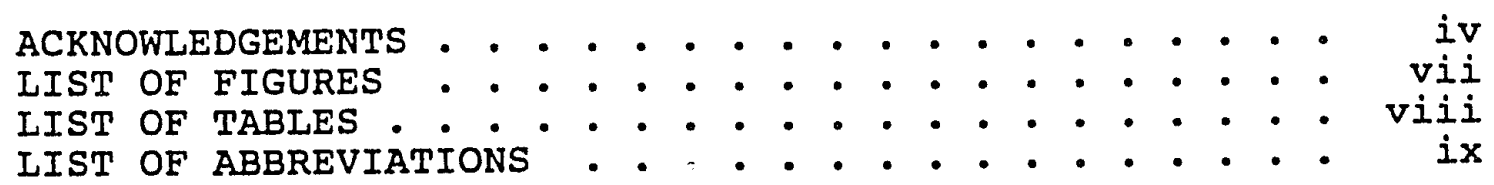

Chapter

I INTRODUCTION •. . . . . . . . . . . . . . . . . 1

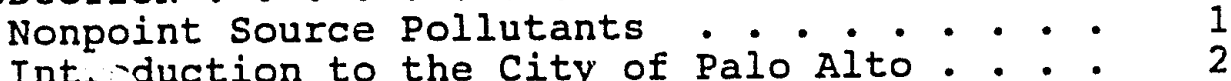

II OBJECTIVES . . . . . . . . . . . . . . 8

III COLLECTION OF NPS DISCHARGE SAMPLES • • • • • • • 9 Sample Collection Dates . . . . . . . . . 9

Sample Collection Sites... . . . . . . 9

Sample Collecting Technique . . . . . . . 16

IV IABORATORY ANAIYSIS OF NPS DISCHARGE SAMPLES . • . 17

Scope of the Study . . . . . . . . . . 17

Pretreatment of the Samples......... 18

Determination of Copper . . . . . . . . 18

Determination of Lead............ 23

V EVALUATION OF NPS DATA . . . . . . . . . . . . 29

First Flush Effect ............. 29

Environmental Fate of Copper and Lead

in Aquatic Systems .......... . 31

Plume Travel . . . . . . . . . . . . 33

Wind Effect................. . 34

Bay Intrusion . . . . . . . . . . . 34

Mass Balance ............... 35

Regional Effort.... . . . . . . . . 36 


\section{TABLE OF CONTENTS}

VI CONSTRUCTED WETLANDS • . . . . . . . . . . . 37

Definition of Wetlands . . . . . . . . 37

Function of Wetlands . . . . . . . . . 38

Feasibility of Constructing Fresh

Water Wetlands at the Palo Alto

Flood Basin... . . . . . . . . 40

Guidelines for Constructing Fresh

Water Wetlands ........... . 43

VII CONCLUSION . . . . . . . . . . . . . . . 47

Appendix

I RAINFALI RECORD IN THE PALO ALTO AREA • • • • • 49

I CALIBRATION AND CALCULATION OF THE COPPER

CONCENTRATIONS .................. . . 50

Sample Batch One . . . . . . . . . . 51

Sample Batch Two . . . . . . . . • • 52

III CALIBRATION AND CALCULATION OF THE LEAD

CONCENTRATIONS . . . . . . . . . . . . . . 54

Sample Batch One . . . . . . . . . . 54

Sample Batch Two .. . . . . . . . . . 55

Sample Batch Three ........... . 56

Sample Batch Four . . . . . . . . . . 57

Sample Batch Five . . . . . . . . . 59

VI EVALUATION OF DATA MEASUREMENT QUALTTY • . • • • 61

Precision . . . . . . . . . . . . 61

Accuracy ................ 63

Measurement Quality Conclusion . . . . . 64

BIBLIOGRAPHY . . . . . . . . . . . . • • . 65

vi 


\section{LIST OF FIGURES}

Figure

1. Map of San Francisco Bay and study area . . . . . 3

2. Map of creeks and watersheds . . . . . . . . . . 5

3. Map of Palo Alto Flood Basin and sample sites • . 6

4. S1 Sample site . . . . . . . . . . . . . 11

5. S3 sample site . . . . . . . . . . . . . 12

6. S4 sample site.................... 13

7. S4 sample site with storm water discharging . . . 14

8. Ml sample site... . . . . . . . . . . . . 14

9. Al sample site... . . . . . . . . . . . 15

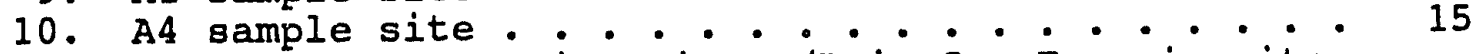

11. Copper concentrations in $\mu \mathrm{g} / \mathrm{I}$ in San Francisquito 21

12. Copper concentrations in $\mu \mathrm{g} / \mathrm{L}$ in the Flood Basin 22

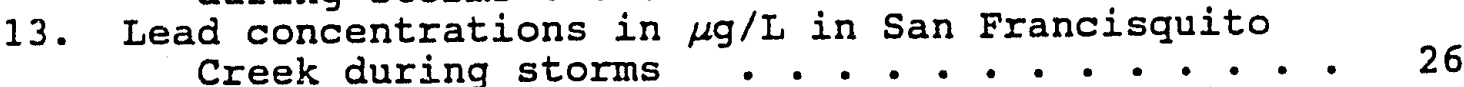

14. Lead concentrations in $\mu \mathrm{g} / \mathrm{L}$ in the Basin during 27

15. First flush phenomenon . . . . . . . . . . . 29

16. Areas around the flood gate . . . . . . . . . 35

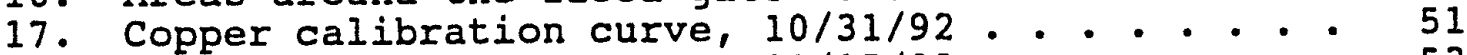

18. Copper calibration curve, $11 / 15 / 92$. . . . . . . . 53

19. Lead calibration curve, 5/21/92 AM . . . . . . . 55

20. Lead calibration curve, 5/21/92 PM . . . . . . . 56

21. Lead calibration curve, 9/2/92 . . . . . . . . . 57

22. Lead calibration curve, $9 / 17 / 92$. . . . . . . 58

23. Lead calibration curve, $10 / 1 / 92$. . . . . . . . 59 


\section{IIST OF TABLES}

Table

1. Inches of Rainfall on sample dates . . . . . . 9

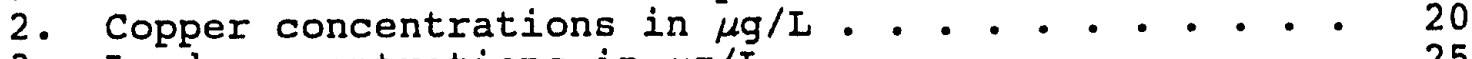

3. Lead concentrations in $\mu \mathrm{g} / \mathrm{L}$. . . . . . . . . . . . 25

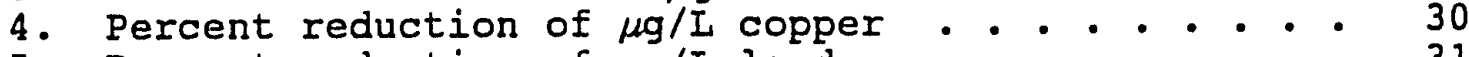

5. Percent reduction of $\mu \mathrm{g} / \mathrm{L}$ lead $\cdot . \cdot \cdot \cdot \cdot \cdot \cdot \cdot \cdot \cdot \cdot 31$

6. Metal pollutants concentrations in $\mu g / L$ of runoff from the four major creeks in the Palo Alto Area on Oct. 29,1992 . . . . . . . . . . . . . . 42

7. Metal pollutants concentrations in $\mu \mathrm{g} / \mathrm{L}$ of runoff from the four major creeks in the Palo Alto area on Dec. 28, 1992 . . . . . . . . . . . . . 


\section{IIST OF ABBREVIATIONS}

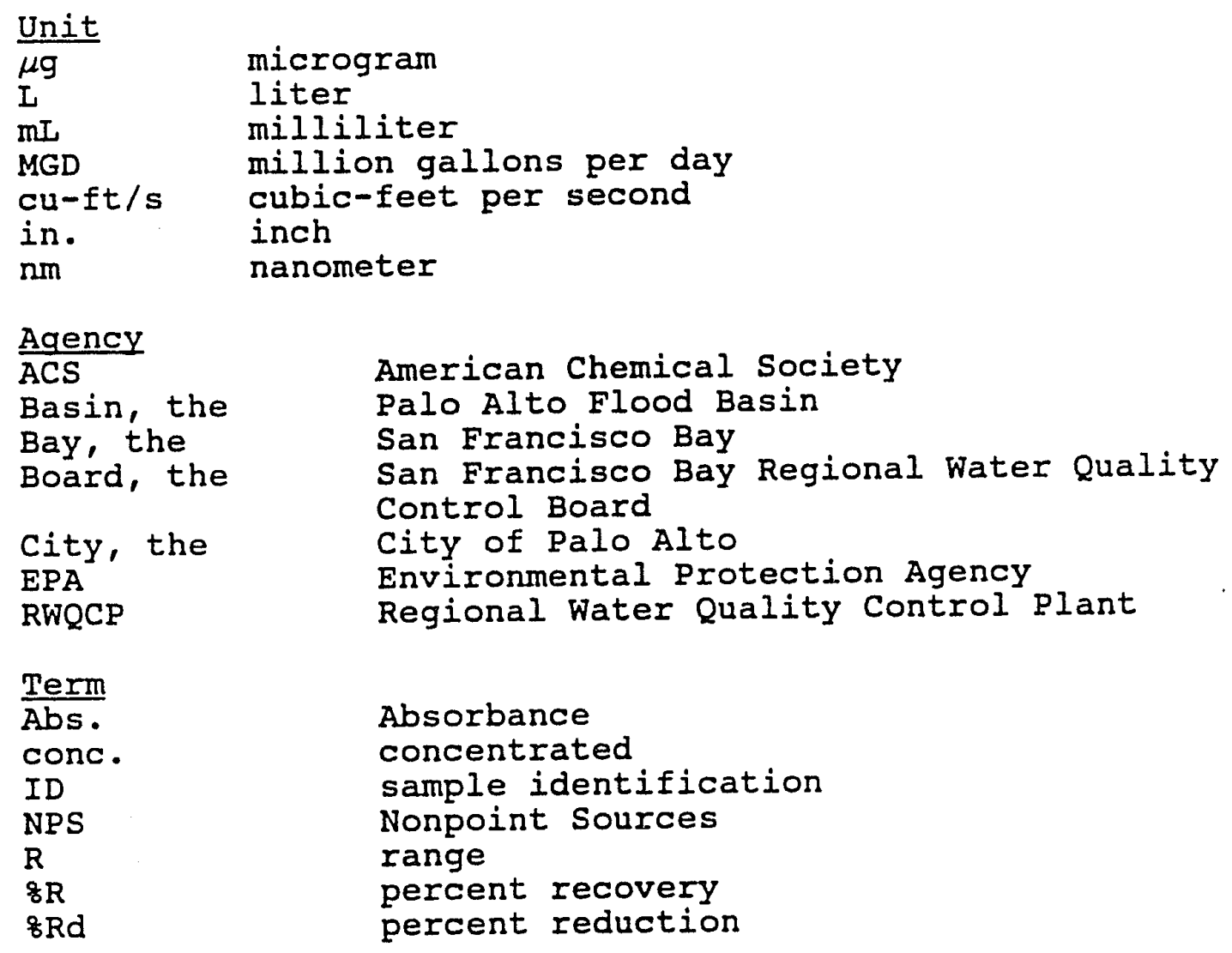


Chapter I

INTRODUCTION

\section{Nonpoint Source Pollutants}

Since the Clean water Act was passed in 1977, much attention has been paid to control point sources. Methods of controlling and/or dealing with nonpoint source (NPS) pollutants, however, have received very little attention until recently.

NPS pollutants are those wastes whose sources cannot be specifically traced. Such pollutants may come from soil erosion, wear and exhaust of automobiles, accidental spill of industrial products, combustion of fossil fuels, mishandling of lawn and garden chemicals, and fecal matter from wild and domestic animals. Pollutants from urban storm water runoff include suspended sediment, organic matter, nutrients, petroleum products, bacteria and viruses, heavy metals, sulfur, acids, and pesticides.

The San Francisco Bay Regional Water Quality Control Board (the Board) has recently issued a permit to a consortium of local governments in the Santa Clara County, including thirteen cities and a water district, for discharging storm water to the San Francisco Bay (the Bay). 
The city of Palo Alto (the City), one of the thirteen cities, is implementing related programs to tackle the NPS pollutant problems. One of its objectives is to determine the actual loading of pollutants released to the Bay.

\section{Introduction to the City of Palo Alto}

The city of Palo Alto is located at the northern end of the Silicon Valley. It is bounded by Menlo Park on the north, Mountain View on the south, and Portola Valley and Los Altos Hills on the west. On its eastern side is East Palo Alto and the Palo Alto Flood Basin (the Basin) which is part of the Palo Alto Baylands Nature Preserve. Fig. 1 provides a study area map of the Bay Area. With a total area of $23.7 \mathrm{sq}$. miles $(15,200$ acres $)$ and a population of 55,900 , the city is a typical urban city with residential areas, industrial parks, general offices, and recreation parks (Hornor 1992, 290).

Virtually all of the City's surface streets are paved. With Interstate Freeway 280 passing through its western hillside and state Highway 101 through its eastern side, the average daily traffic flow in the city streets, based on a survey done in 1984 and assuming a 28 yearly increase, is about 35,000 vehicle counts per day. The traffic flow on Highway 101 is 104,000 counts per day while Freeway 280 has 


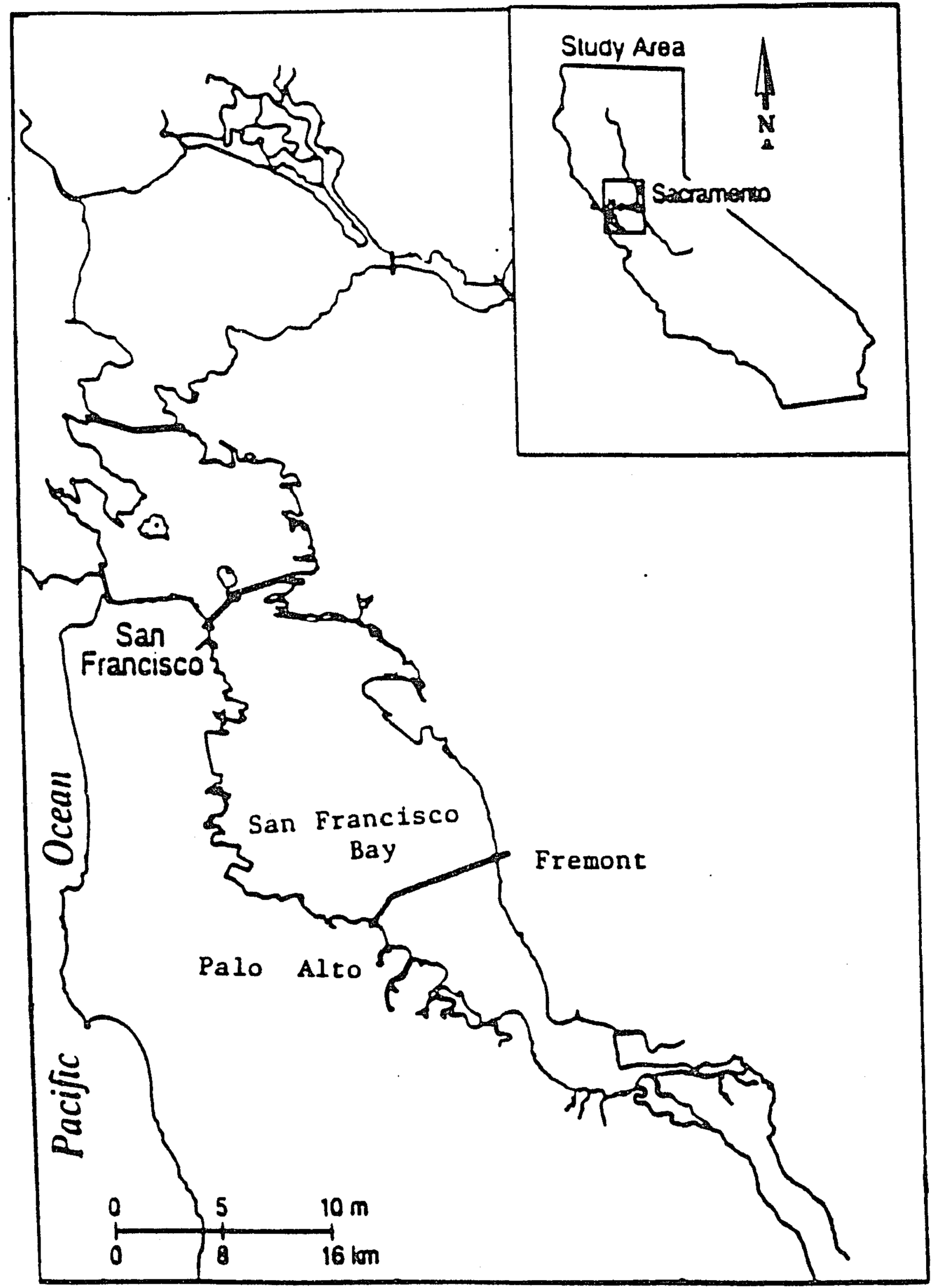

Fig. 1.--Map of San Francisco Bay and study area 
82,200 counts (City of Palo Alto 1984).

There are thirteen catchments within the city to collect all the storm water which eventually discharges to the four major creeks that go through the City. As shown in Fig. 2, San Francisquito Creek, which borders the City on its northern edge, discharges directly into the Bay. Matadero Creek and Barron Creek are located in the middle part of the City while Adobe Creek passes through the City in the south. Since Barron Creek merges with Matadero Creek right before entering the Basin, Barron is considered as part of Matadero in this study. Matadero Creek and Adobe Creek both discharge into the Basin.

The Basin includes 600 acres of marshlands. There is a flood gate in the outlet of the Basin that allows Bay water to pass in and out. The water level is maintained at approximately minus two feet below sea level during dry seasons. In wet seasons, the water level varies.

Immediately adjacent to the Basin there is an active refuse disposal area, a park (Byxbee Park), and two newly constructed marshlands, both completed in 1992, as shown in Fig. 3. The first marsh, ITT Marsh, is a fresh water marsh that includes a 15-acre pond three to four feet deep. It remains dry in summer and is filled with reclaimed water from the Regional Water Quality Control Plant (RWQCP) during non-summer months. When operating, approximately $0.7-1$ 


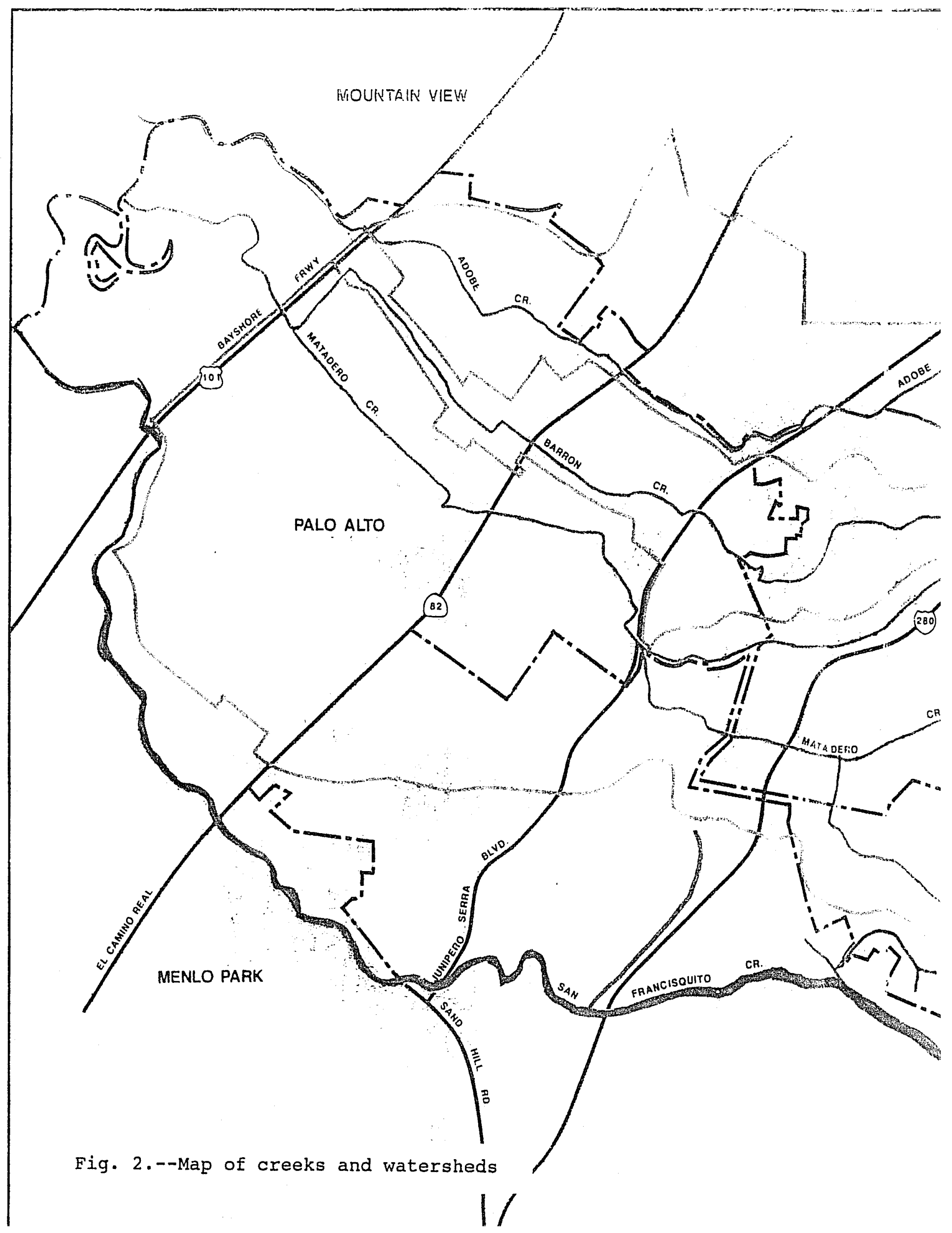




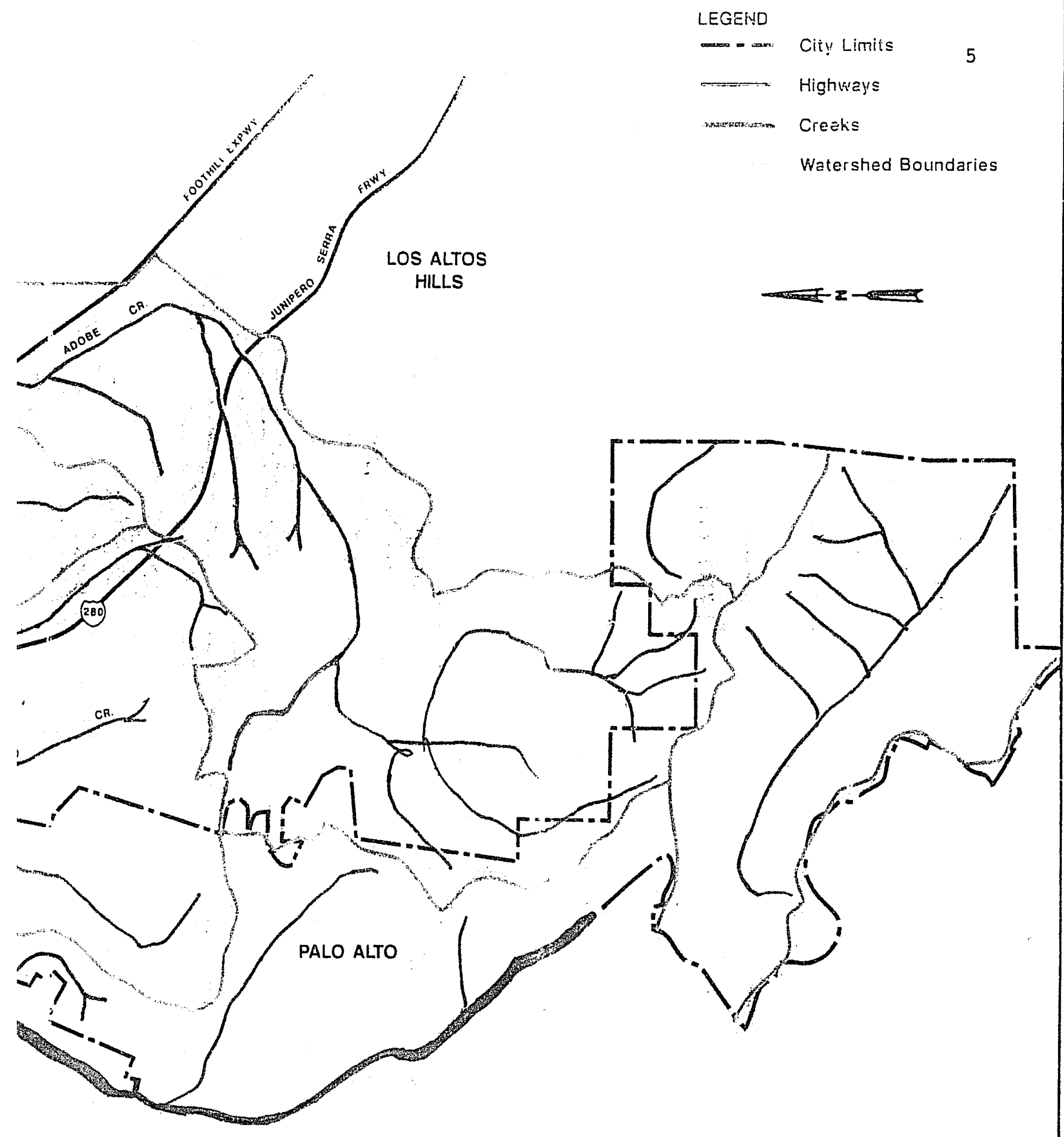




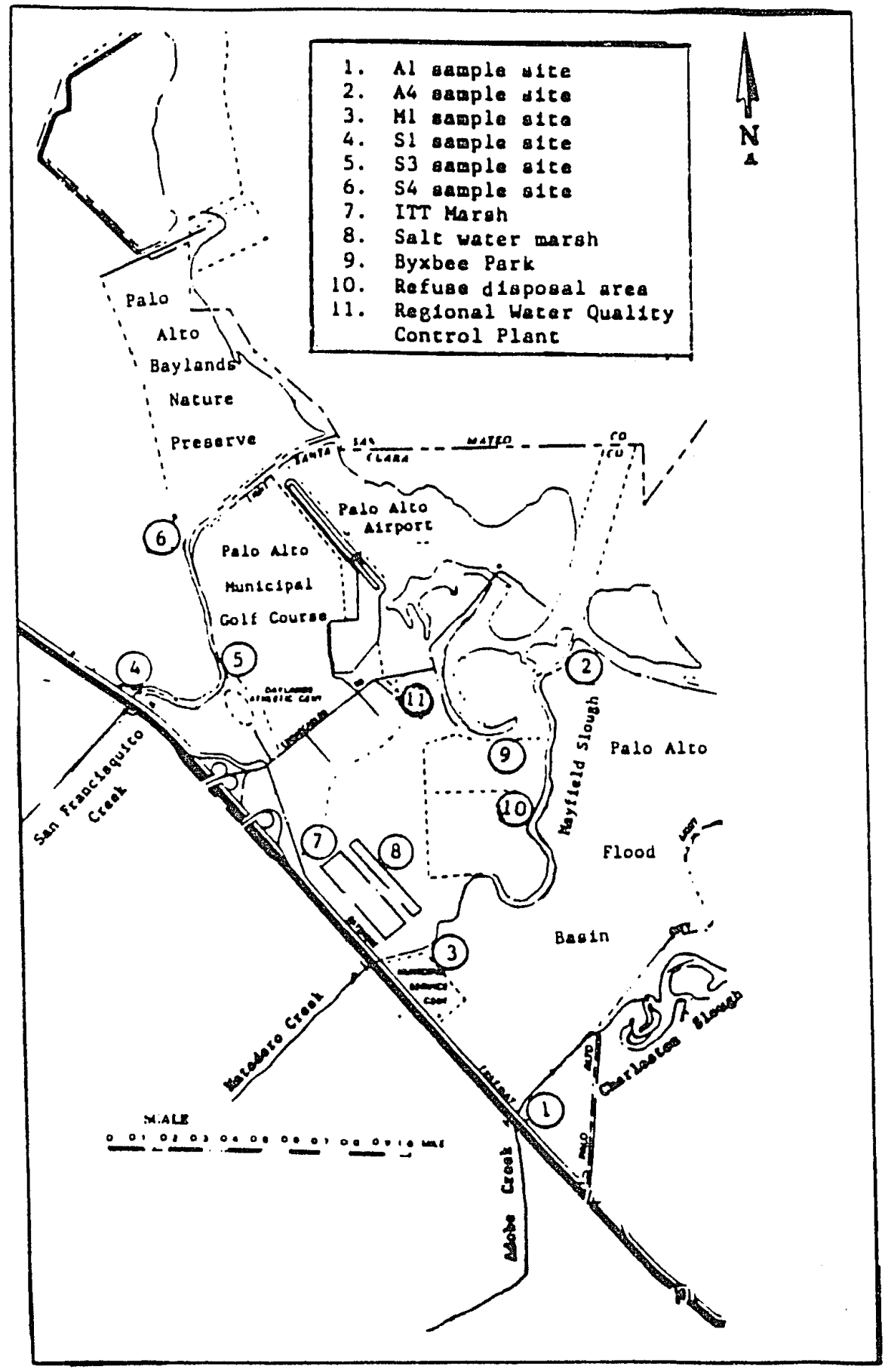

Fig. 3.--Map of Palo Alto Flood Basin and sample sites 
million gallons per day (MGD) of fresh water flows through the pond and discharges to Matadero Creek. The second marsh is a salt water marsh. It consists of approximately 12 acres of wetlands habitat along the eastern side of the ITT Marsh. A water surface elevation of approximately minus two feet below sea level is maintained by pumping water out of the marsh to Matadero Creek and by controlling the incoming tidal water. The salt water marsh is maintained year-round with a flow of approximately 1 MGD of Bay water flowing through. Together, the two marshes provide essential habitat for wildlife, particularly for the salt marsh harvest mouse. 
Chapter II

OBJECTIVES

There are two objectives in this thesis. The first objective is to determine a profile of pollutants from nonpoint source pollutants discharge before they reach the San Francisco Bay or the Palo Alto Flood Basin by analyzing samples collected during storm events for copper and lead content. The second objective is to explore the feasibility of constructing multi-purpose fresh water wetlands as a treatment option, and if feasible, provide some guidelines for such construction. 


\section{Chapter III \\ COLLECTION OF NPS DISCHARGE SAMPLES}

\section{Sample Collection Dates}

Six sets of samples were taken during or right after the first few storms in 1991-1992. Dates and respective rainfall recorded at the Palo Alto Fire Station (US Department of Commerce 1991 \& 1992) are listed below in Table 1 :

\begin{tabular}{||l|l|l|l|l|l|l|}
\hline Date & $10 / 26$ & $12 / 7$ & $12 / 28$ & $12 / 29$ & $1 / 5$ & $2 / 15$ \\
\hline Rainfall & 0.08 & 0.02 & 0.51 & 1.39 & 0.61 & 0.92 \\
\hline
\end{tabular}

Table 1.--Inches of Rainfall on sample dates

These six days included most of the storm events during the early part of the rainy season. Appendix I provides the daily rainfall for the sampling period.

\section{Sample Collection sites}

There were six sample sites: three on San Francisquito Creek, one on Matadero Creek, one on Adobe Creek, and one on 
the Basin outlet. It should be noted that all six sample sites were intruded upon by Bay water to different extents depending on tide level. Thus the metal concentrations obtained may be from a combination of both storm water and Bay water. An adjustment for this combination may be necessary if the concentration from the samples is comparable to that of Bay water.

A map of the sampling sites is shown in Fig. 3 . Descriptions of each are listed as follows:

1. San Francisquito Creek:

a) S1:

SI is located at the intersection of San Francisquito Creek and East Bayshore Road under the bridge as shown in Fig. 4 .

b) S3:

S3 is located downstream of $\mathrm{S1}$, next to the Baylands Athletic center as shown in Fig. 5 .

c) $54:$

S4 is located further down the Creek, under the bridge connecting the City and East Palo Alto. There is a San Mateo storm water discharge station which collects storm water from East Palo Alto just upstream of this site as shown in Fig. 6 . On $2 / 15 / 92$, a sample was taken from this site while storm water was discharging as shown in Fig. 7 . 


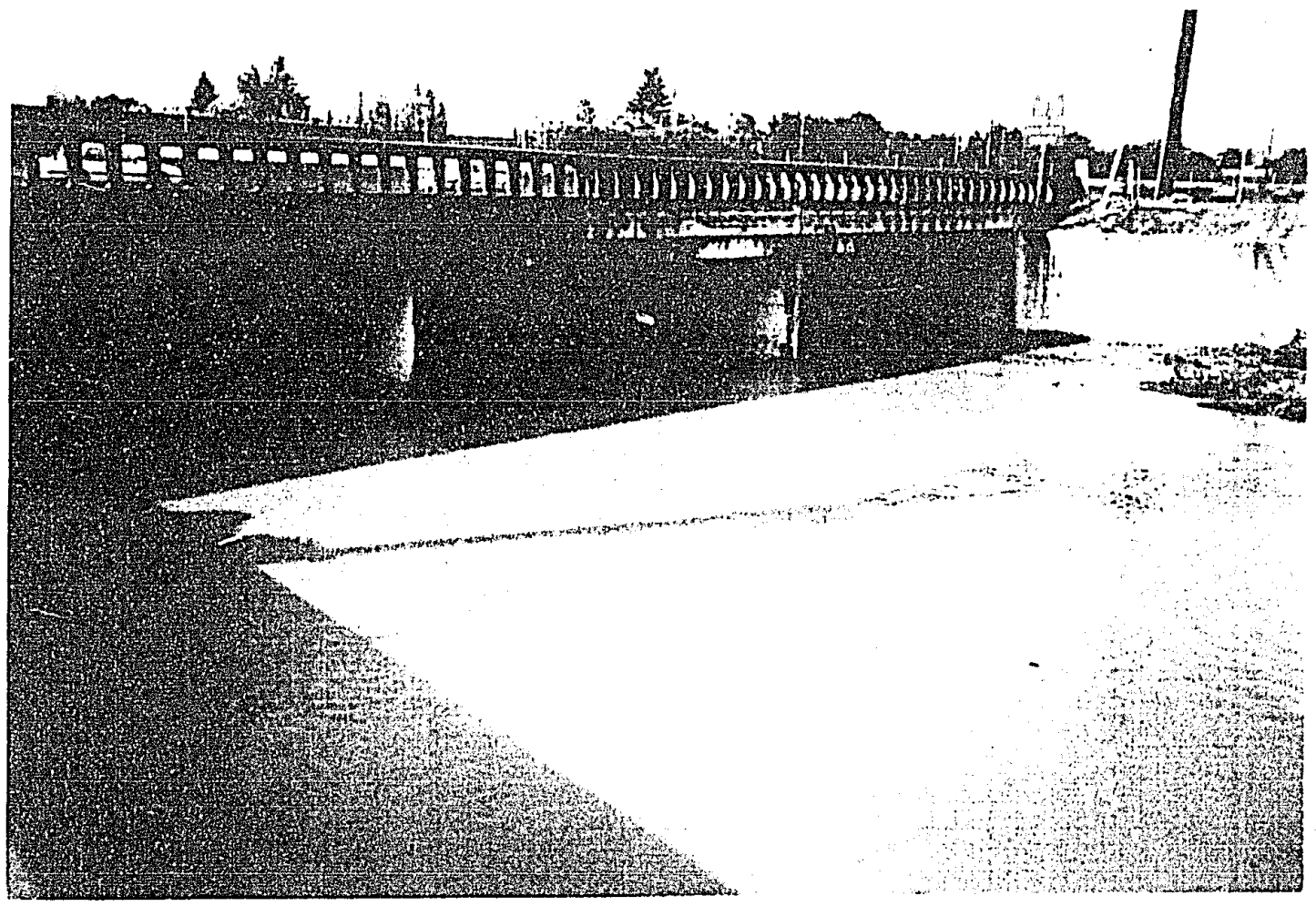

Fig. 4.--S1 Sample site

There is no other storm water discharge downstream from the 54 sample site in San Francisquito Creek. The concentrations obtained from $\$ 4$ should be considered the final concentrations flowing to the Bay.

2. Matadero Creek:

a) MI:

M1 is located at the intersection of the Creek and East Bayshore Road, under the bridge as shown in Fig. 8. Matadero Creek constitutes one of the inlets of the Basin. 

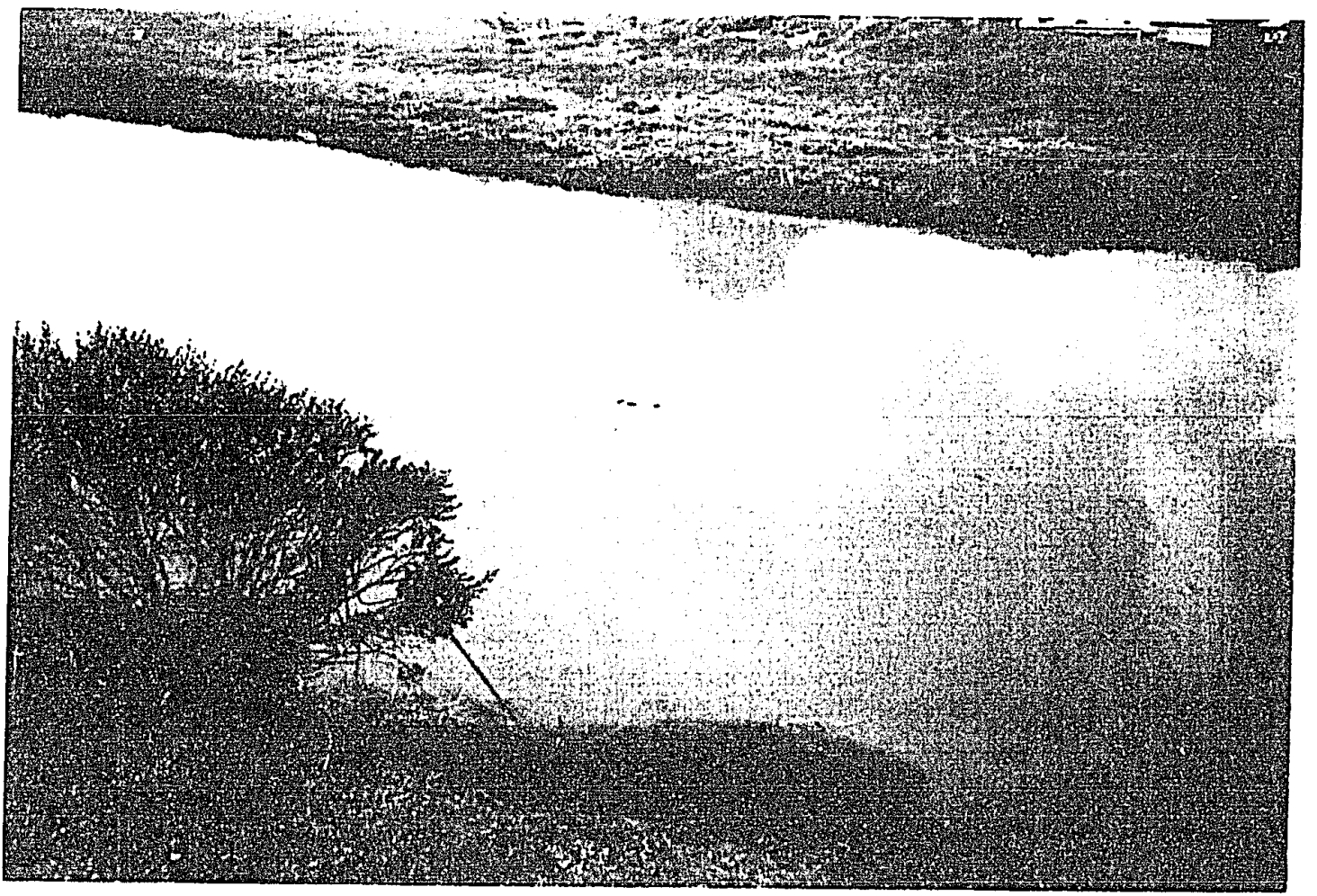

Fig. 5.--S3 sample site

3. Adobe Creek:

a) A1:

A1 is located at the intersection of the Creek and

East Bayshore Road, under the bridge as shown in

Fig. 9. Adobe Creek is the other inlet to the Basin. 


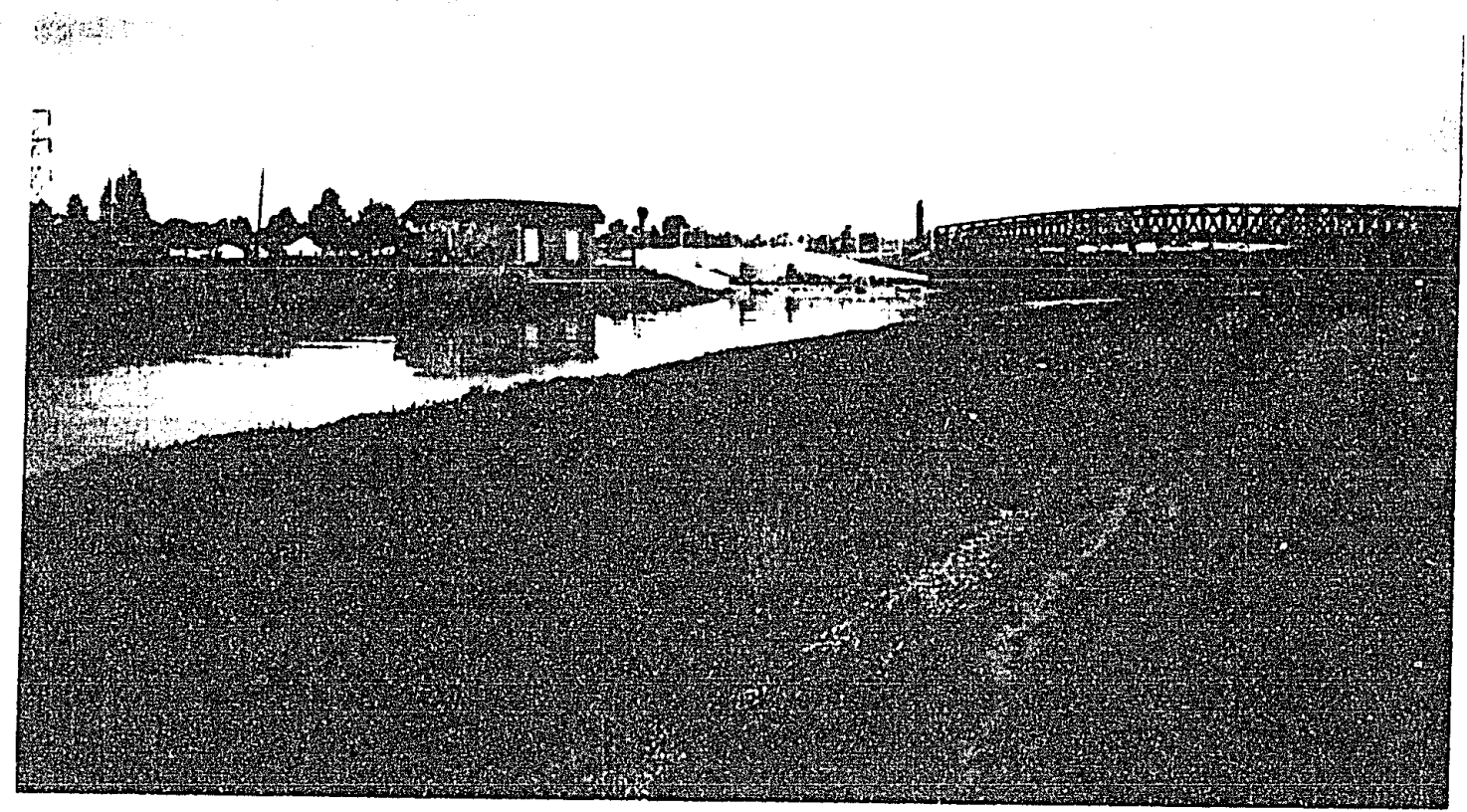

Fig. 6.--S4 sample site

\section{Flood Basin Outlet:}

a) A4:

A4 is located at the southern side of the outlet pump station inside the Flood Basin as shown in Fig. 10. The outlet is considered the last discharge point from both Matadero Creek and Adobe Creek. 


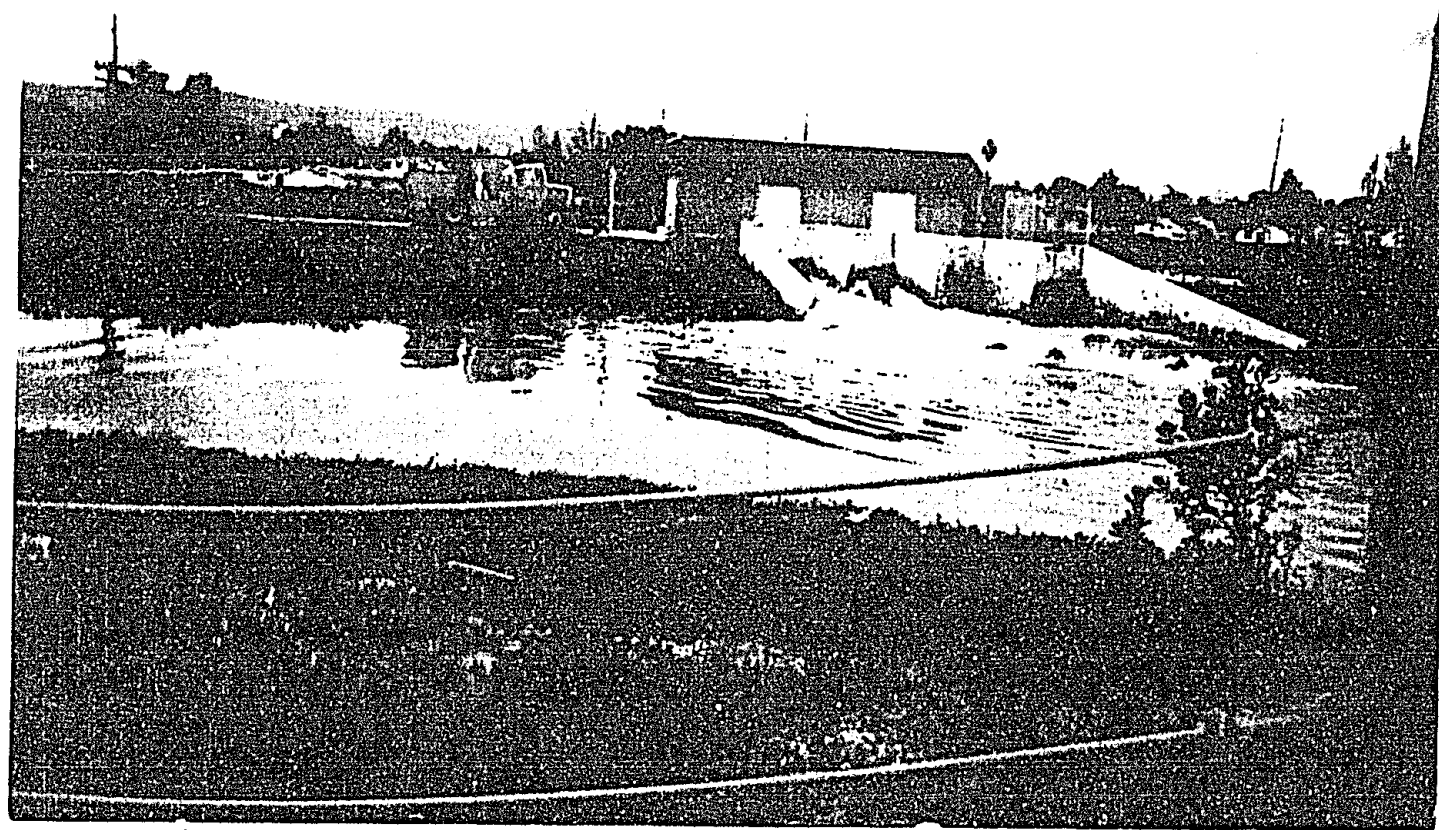

Fig. 7.--S4 sample site with storm water discharging

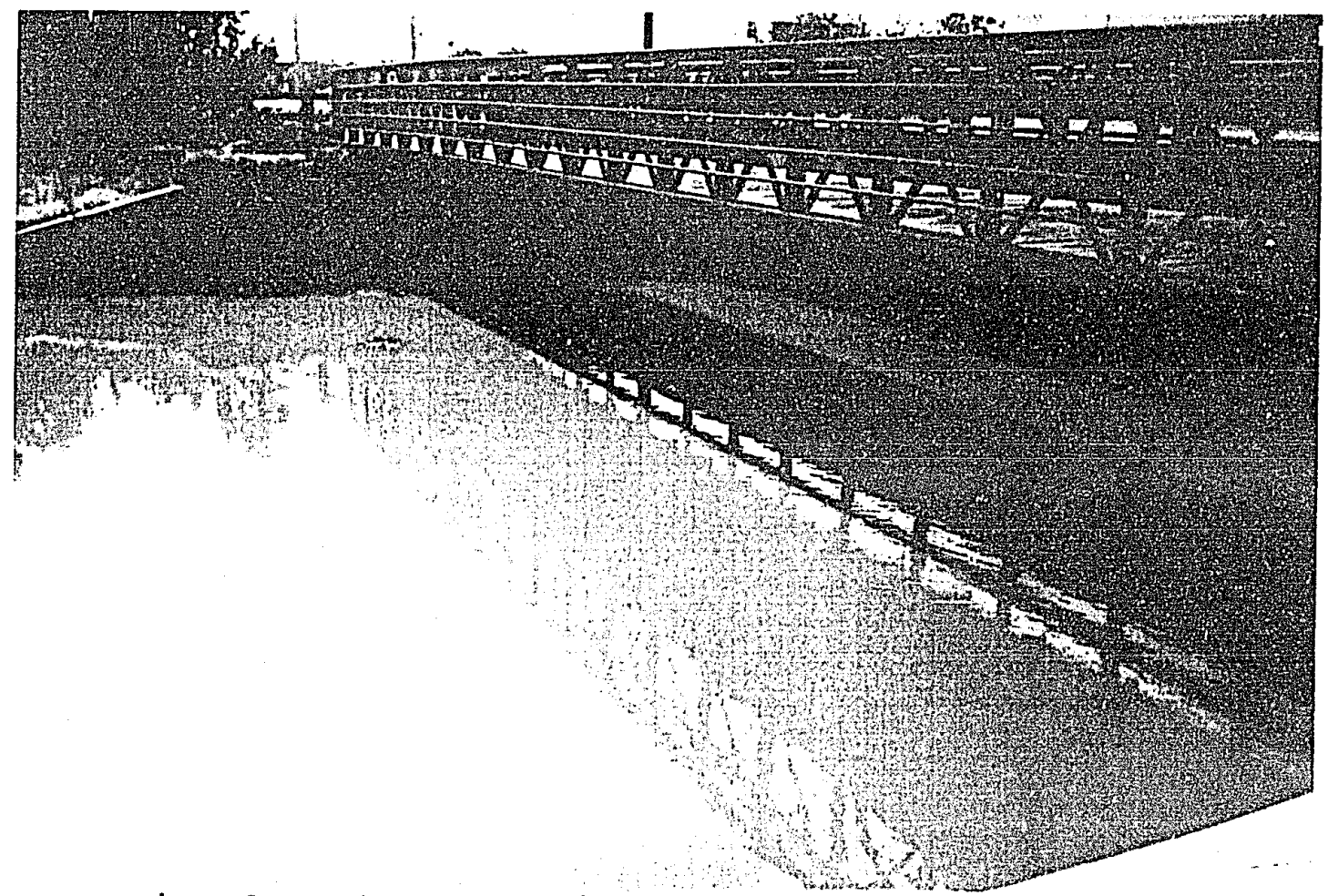

Fig. 8.--Ml sample site 


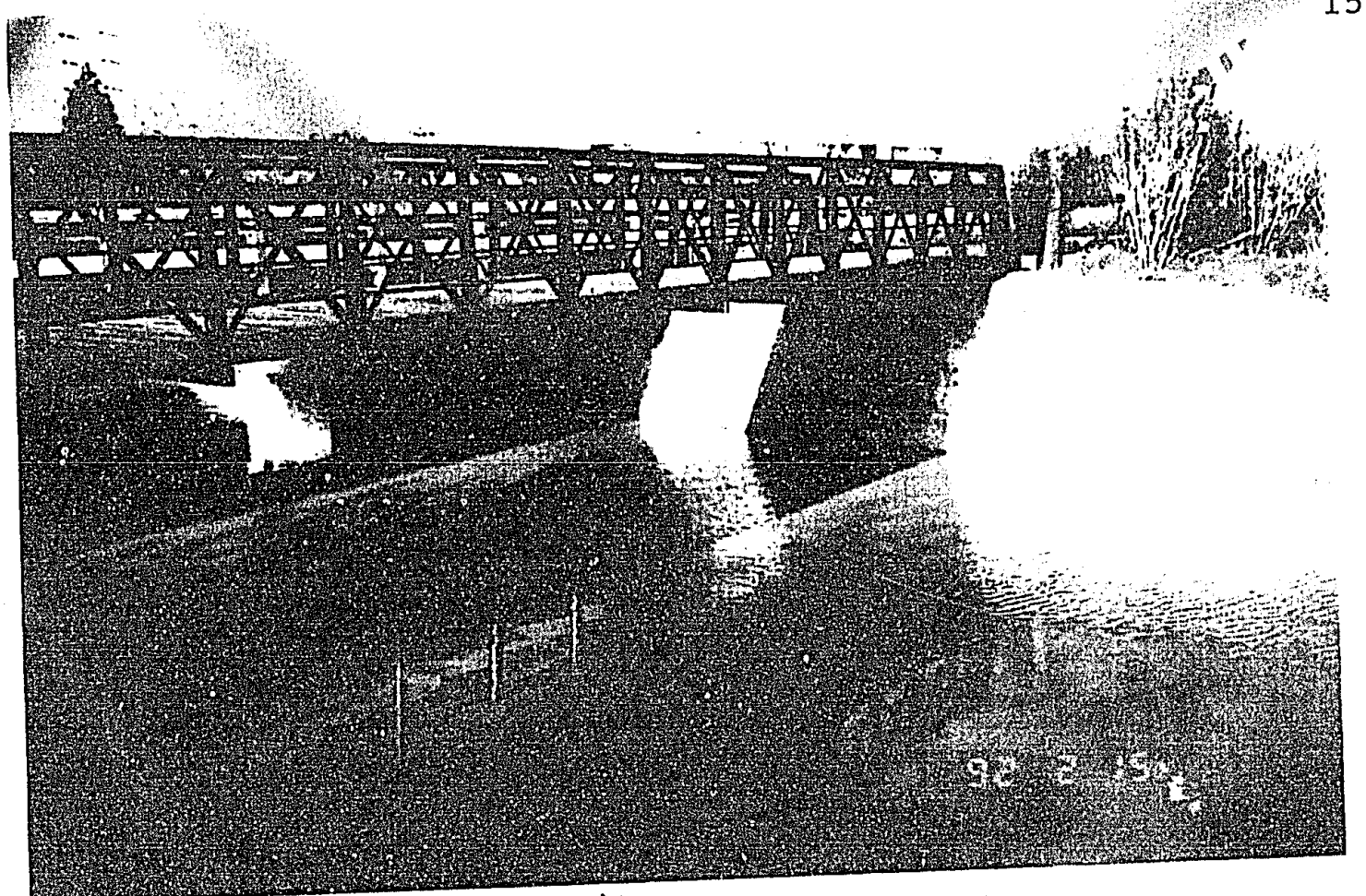

Fig. 9.--A1 sample site

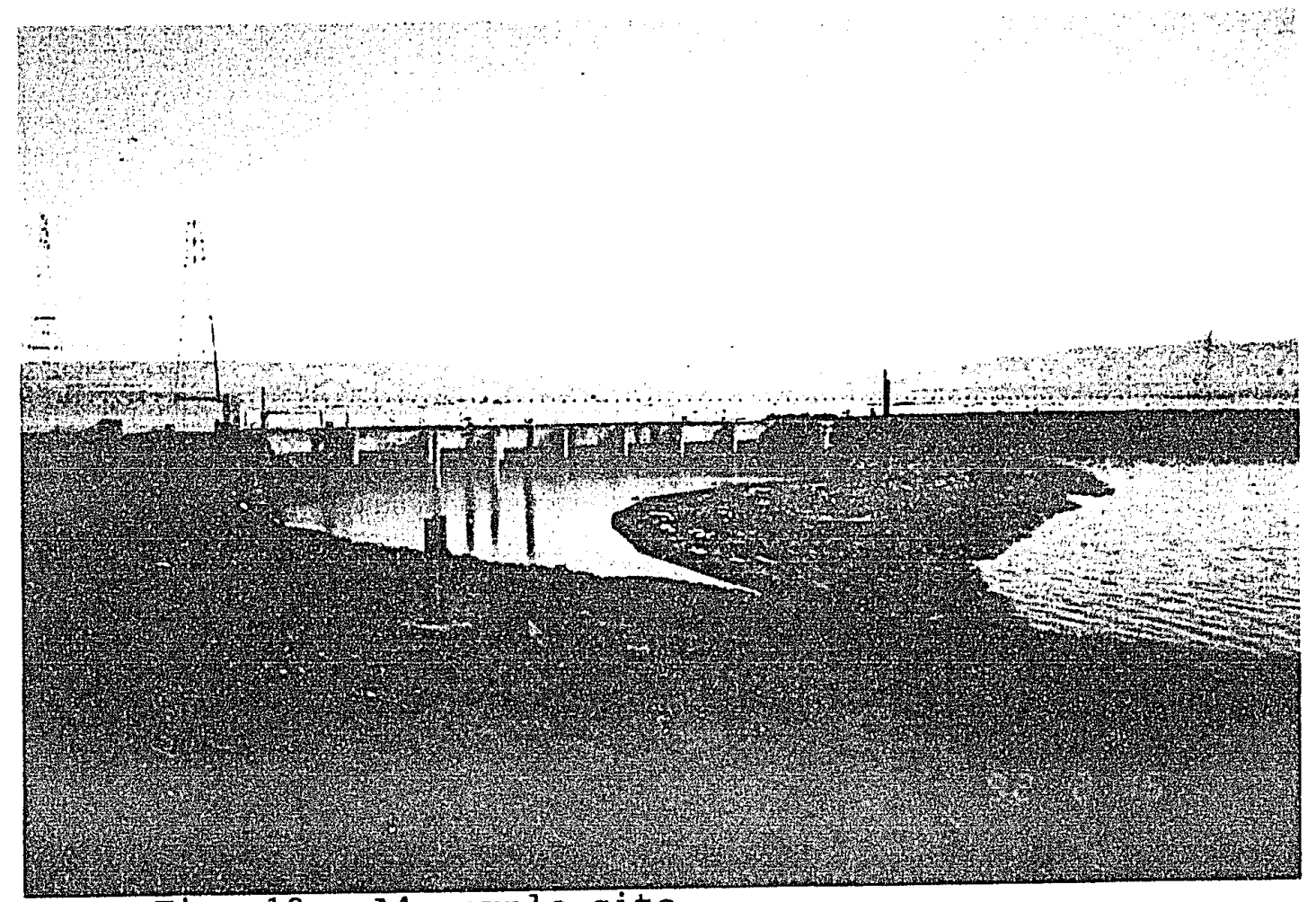

Fig. 10.--A4 sample site 
Sample Collecting Technique

A grab sample was taken at each site by tying an acidrinsed bottle to a string and lowering it to the creek to obtain a surface water sample. Immediately after collection, samples were preserved with nitric acid to a $\mathrm{pH}$ of less than 2 in sample containers to prevent loss of metals by adsorption and/or precipitation. 


\title{
Chapter IV \\ IABORATORY ANALYSIS OF NPS DISCHARGE SAMPLES
}

\begin{abstract}
Samples were transferred to a laboratory in Duncan Hall, San Jose State University for analysis. The metal concentrations were determined by spectrophotometric methods. The bathocuproine method (Greenberg, Connors, and Jenkins 1980,193 ) was used to determine the concentration of copper, while the dithizone method (Greenberg, Connors, and Jenkins 1980,207 ) was used to determine the concentration of lead.
\end{abstract}

\section{Scope of the study}

Heavy metals such as copper and lead can find their way to the environment from common household products, automobile exhaust, industrial smelters, etc. Once emitted to the air, they, along with other pollutants, are deposited on street surfaces until washed off by rain or street sweeping. Based on these characteristics, copper and lead were chosen as indicators of the level of pollution. 


\section{Pretreatment of the Samples}

Other than the acid added for preservation, the samples were not subjected to vigorous heat digestion prior to analysis in order to avoid contamination from glassware. Therefore the concentrations obtained should be considered as acid-soluble metals in surface water.

\section{Determination of Copper}

The following method describes the determination of copper(II) ion concentrations in the NPS discharge samples: 1. Apparatus and equipment

a) Hewlett-Packard 8451A Diode Array UV-VIS Spectrophotometer equipped for a $1-\mathrm{cm}$ sample cell

b) Acid-washed glassware:

All glassware was rinsed with conc. $\mathrm{HNO}_{3}$ and then distilled water.

\section{Reagents}

a) Stock standard copper solution:

One liter of $1000 \mathrm{mg} / \mathrm{L}$ American Chemical

Society (ACS) grade copper(II) standard solution was purchased from J.T. Baker, Inc.

b) Working standard copper solution:
A $1000 \mu \mathrm{g} / \mathrm{L}$ working solution was prepared by diluting $1.00 \mathrm{~mL}$ of the $1000 \mathrm{mg} / \mathrm{I}$ stock solution to 1 liter with distilled water containing $18 \mathrm{BNO}_{3}$. 
c) Hydrochloric acid:

$\mathrm{HCl}, 1: 1$.

d) Hydroxylamine hydrochloride solution:

Dissolved $25 \mathrm{~g} \mathrm{NH}_{2} \mathrm{OH} . \mathrm{HCl}$ in $225 \mathrm{Ml}$ distilled water.

f) Sodium citrate solution:

Dissolved $75 \mathrm{~g} \mathrm{Na}_{3} \mathrm{C}_{6} \mathrm{H}_{5} \mathrm{O}_{7} \cdot 2 \mathrm{H}_{2} \mathrm{O}$ in distilled water to make a $250 \mathrm{~mL}$ solution.

g) Disodium bathocuprine disulfonate solution:

Dissolved $0.25 \mathrm{~g} \mathrm{C}_{12} \mathrm{H}_{4} \mathrm{~N}_{2}\left(\mathrm{CH}_{3}\right)_{2}\left(\mathrm{C}_{6} \mathrm{H}_{4}\right)_{2}\left(\mathrm{SO}_{3} \mathrm{Na}\right)_{2}$ in

distilled water to make a $250 \mathrm{ml}$ solution.

3. Procedure

A $50.0 \mathrm{~mL}$ water sample was mixed with $1.0 \mathrm{~mL} 1: 1 \mathrm{HCl}$, $5.0 \mathrm{~mL}$ hydroxylamine.HCl solution, $5.0 \mathrm{~mL}$ sodium citrate solution and $5.0 \mathrm{~mL}$ disodium bathocuprine disulfonate solution. The solution was carefully stirred during each addition. The final orange-colored solution was transferred to a $1-\mathrm{cm}$ cell and the absorbance was read against the reagent blank at a wavelength of $484 \mathrm{~nm}$ in the spectrophotometer. A reagent blank and a separate set of standard solutions containing 1 to 20 or $50 \mu \mathrm{g}$ were run with each set of samples. In addition, to ensure measurement quality, one sample out of each batch was run in duplicate and also rerun with the addition of a measured amount of standard solution (Method of Standard Addition). A Quattro Pro spreadsheet was used to calculate a best fit curve of absorbance versus 
$\mu g$ of copper standards for a calibration curve and subsequently used to calculate the $\mu g$ of copper in the 50.0 mI sample.

4. Data

A summary of data was tabulated in Table 2 in $\mu \mathrm{g} / \mathrm{I}$ and graphed in Fig. 11 and 12. Refer to Appendix II for detailed calculation.

\begin{tabular}{|l|l|l|l|l|l|l||}
\hline Date & M1 & A1 & A4 & S1 & S3 & S4 \\
\hline $10 / 26$ & 64 & 80 & 55 & 88 & 130 & 97 \\
\hline $12 / 7$ & 53 & 160 & 63 & 65 & 61 & 46 \\
\hline $12 / 28$ & 79 & 74 & 150 & 100 & 71 & 71 \\
\hline $12 / 29$ & 29 & $<20$ & $<20$ & $<20$ & $<20$ & 62 \\
\hline $1 / 5$ & 55 & $<20$ & 29 & $<20$ & 71 & 50 \\
\hline $2 / 15$ & 32 & 31 & 95 & 34 & 31 & 45 \\
\hline
\end{tabular}

Table 2.--Copper concentrations in $\mu \mathrm{g} / \mathrm{L}$

5. Discussion of the Copper Procedure

In this method, copper(II) ion is reduced to cuprous ion, $\mathrm{Cu}^{+}$, by hydroxylamine hydrochloride at $\mathrm{pH}$ around 4.3 . One mole of cuprous ion, in turn, chelates with 2 moles of 
bathocuprine disulfonate (2,9-dimethyl-4,7-diphenyl-1, 10phenanthroline disulfonic acid) to form an orange-colored solution which gives an absorbance peak at a wavelength of $484 \mathrm{~nm}$ (Marczenko 1986, 262).

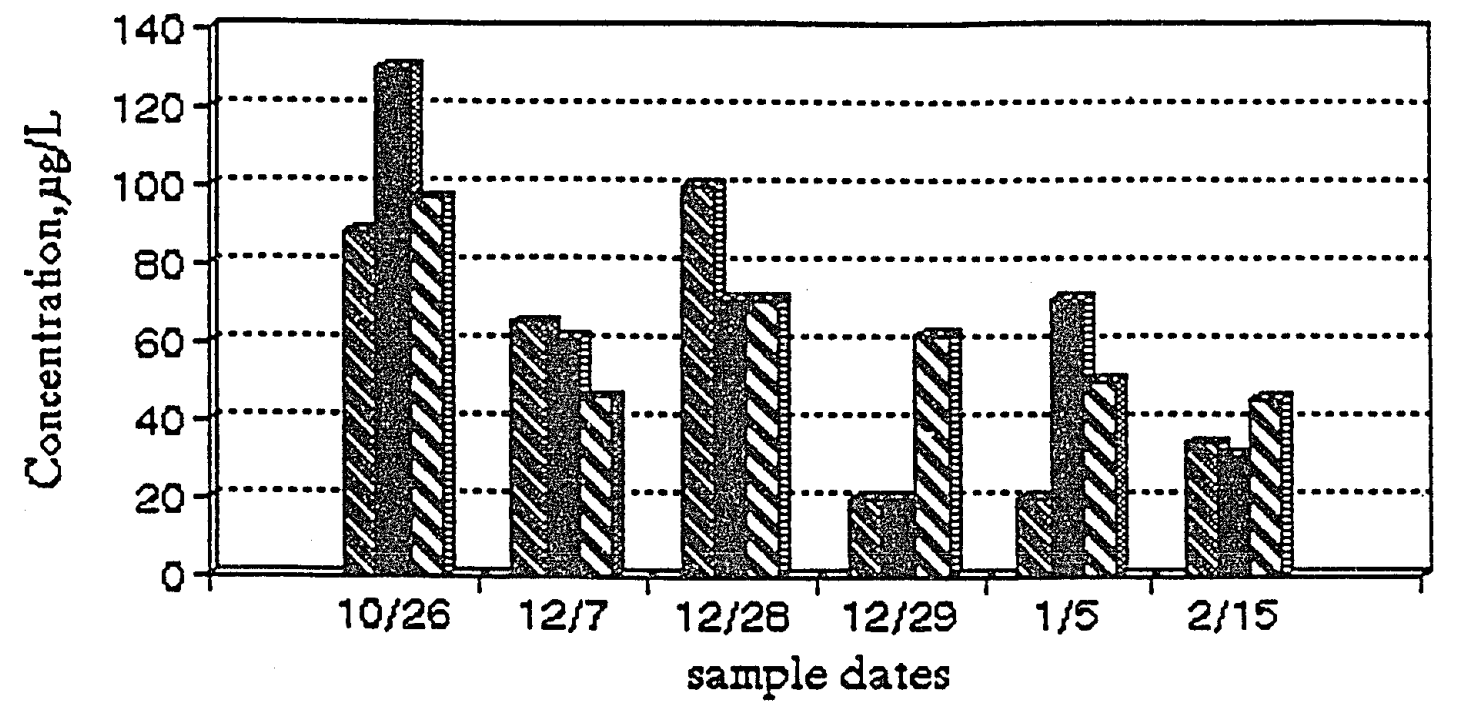

Site S1 Site S3 DIV Site S4

Fig. 11.--Copper concentrations in $\mu \mathrm{g} / \mathrm{L}$ in $\mathrm{San}$ Francisquito Creek during storms

Since the disodium bathocuprine disulfonate is soluble in water, this method is quite straight forward. The color remains stable for at least two hours.

Two calibration curves were prepared on two different days. While both showed linearity above $1 \mu \mathrm{g}$, there was an obvious bend below $1 \mu \mathrm{g}$, indicating that the calibration 
limit for copper was $1 \mu \mathrm{g}$. With a $50.0 \mathrm{~mL}$ sample size, the value was thus transformed to $20 \mu \mathrm{g} / \mathrm{L}$ as shown in Equation 1:

$$
\frac{1 \mu \mathrm{g}}{50.0 \mathrm{~mL}} \times \frac{1000 \mathrm{~mL}}{1 \mathrm{~L}}=20.0 \mu \mathrm{g} / \mathrm{L}
$$

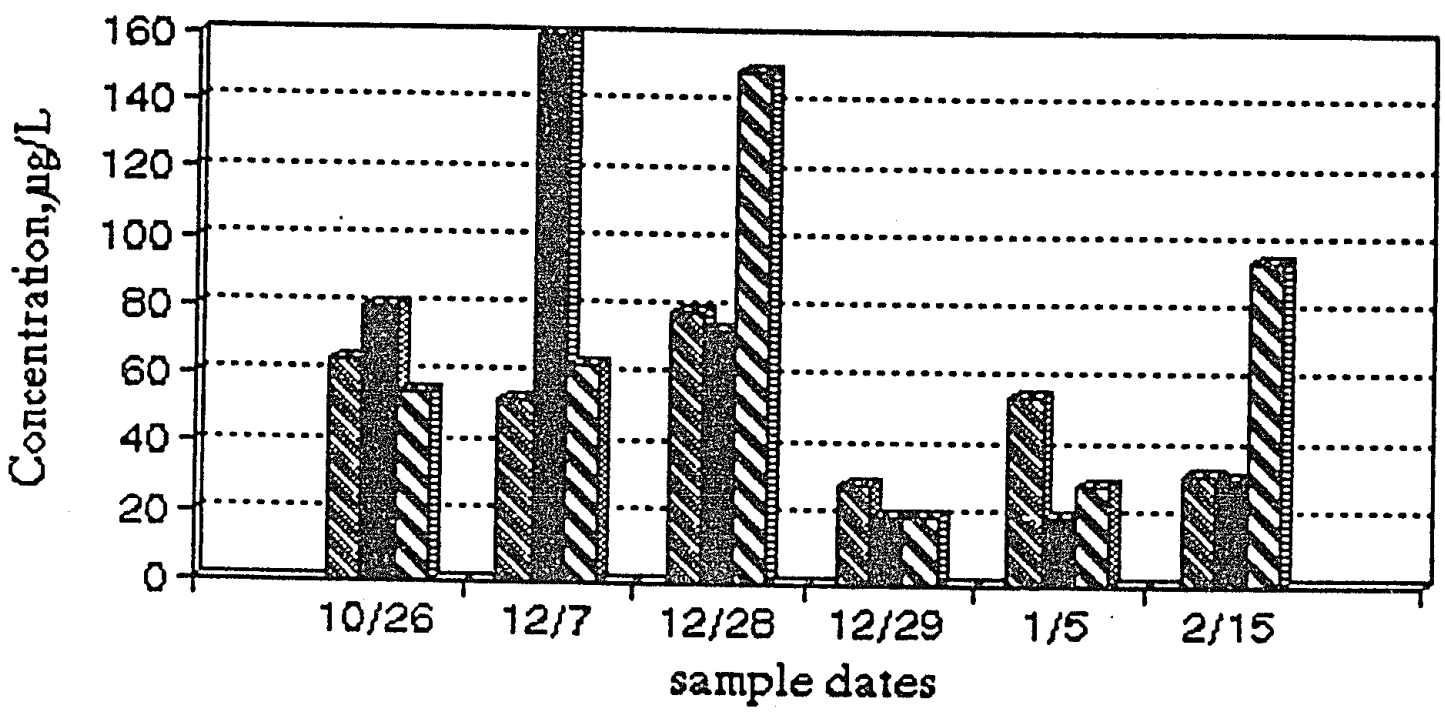

\section{Site M1 Site A1 Site A4}

Fig. 12.--Copper concentrations in $\mu \mathrm{g} / \mathrm{I}$ in the Flood Basin during storms

On each batch, one sample was duplicated and also spiked with a measured amount of standard to ensure measurement quality. As shown in Appendix IV, the precision range of the first set was $0.6 \mu \mathrm{g}$, with an accuracy recovery of 898 . The second set, however, was irrelevant due to the 
fact that the concentration of the sample was below the calibration limit.

\section{Determination of Lead}

The following method describes the determination of lead in the NPS discharge samples.

1. Apparatus and equipment

Refer to Section A.1 of this Chapter.

2. Reagents

a) Stock standard lead solution:

One liter of $1000 \mathrm{mg} / \mathrm{L}$ of ACS grade lead standard solution was purchased from J.T. Baker, Inc.

b) Working standard lead solution:

A $1000 \mu \mathrm{g} / \mathrm{L}$ working solution was prepared by diluting $1.00 \mathrm{~mL}$ of the $1000 \mathrm{mg} / \mathrm{L}$ stock standard solution to 1 liter with distilled water in 18 $\mathrm{HNO}_{3} \cdot$

c) Nitric acid: $\mathrm{HNO}_{3}, 1: 4$.

d) Ammonium hydroxide:

$\mathrm{NH}_{4} \mathrm{OH}, 1: 9$.

e) Citrate-cyanide reducing solution:

Dissolved $66 \mathrm{~g}$ dibasic ammonium citrate, $\left(\mathrm{NH}_{4}\right) \mathrm{HC}_{6} \mathrm{H}_{5} \mathrm{O}_{7}, 3.3 \mathrm{~g}$ anhydrous sodium sulfite, $\mathrm{Na}_{2} \mathrm{SO}_{3}, 1.6 \mathrm{~g}$ hydroxylamine hydrochloride, 
$\mathrm{NH}_{2} \mathrm{OH} . \mathrm{HCl}$, and $6.6 \mathrm{~g}$ potassium cyanide, $\mathrm{KCN}$, in 166 $\mathrm{mL}$ distilled water and mixed with $333 \mathrm{~mL}$ conc. $\mathrm{NH}_{4} \mathrm{OH}$.

f) Stock dithizone solution:

Dissolved $40 \mathrm{mg}$ dithizone in $250 \mathrm{~mL}$ chloroform.

g) Intermediate dithizone solution: Diluted $50 \mathrm{~mL}$ of the stock in $200 \mathrm{~mL}$ chloroform.

h) Working dithizone solution:

Diluted $10 \mathrm{~mL}$ of the intermediate solution with chloroform to make a $100 \mathrm{~mL}$ solution. This solution was made freshly every time.

\section{Procedure}

A $50.0 \mathrm{~mL}$ sample was transferred to a separatory funnel and mixed with $10.0 \mathrm{~mL}$ of the $1: 4 \mathrm{HNO}_{3}$ and $25.0 \mathrm{~mL}$ of the citrate-cyanide reducing solution. Upon cooling, the resulting solution was mixed with $10.0 \mathrm{~mL}$ working dithizone solution and shook vigorously for 30 seconds. Immediately after the two layers separated, the organic layer was then transferred to a $1-\mathrm{cm}$ cell and absorbance was measured against the working dithizone solution as blank in the spectrophotometer at a wavelength of $510 \mathrm{~nm}$. A reagent blank and a separate set of standard solutions containing 5 to 10 or $20 \mathrm{\mu g}$ were run with each set of samples. In addition, to ensure measurement quality, one sample out of each batch was run in duplicate and also rerun with the 
addition of a measured amount of standard solution (Method of Standard Addition). A Quattro Pro spreadsheet was used to calculate a best fit curve of absorbance versus $\mu \mathrm{g}$ of lead in standard solution for a calibration curve and subsequently used to calculate the $\mu \mathrm{g}$ of lead in the $50.0 \mathrm{~mL}$ sample.

4. Data

A summary of the data was tabulated in $\mu \mathrm{g} / \mathrm{I}$ in Table 3 and graphed in Fig. 13 and 14. Refer to Appendix III for detailed calculation.

\begin{tabular}{||l|l|l|l|l|l|l||}
\hline Date & MI & A1 & A4 & S1 & S3 & S4 \\
\hline $10 / 26$ & $<100$ & 310 & 190 & 260 & 290 & 180 \\
\hline $12 / 7$ & $<100$ & 540 & 370 & 270 & 480 & 200 \\
\hline $12 / 28$ & 190 & 180 & 120 & 420 & 380 & 270 \\
\hline $12 / 29$ & 100 & 140 & $<100$ & 110 & $<100$ & 200 \\
\hline $1 / 5$ & $<100$ & 260 & 280 & 260 & 140 & 180 \\
\hline $2 / 15$ & 430 & 390 & 250 & 190 & $<100$ & 230 \\
\hline
\end{tabular}

Table 3.--Lead concentrations in $\mu \mathrm{g} / \mathrm{L}$ 


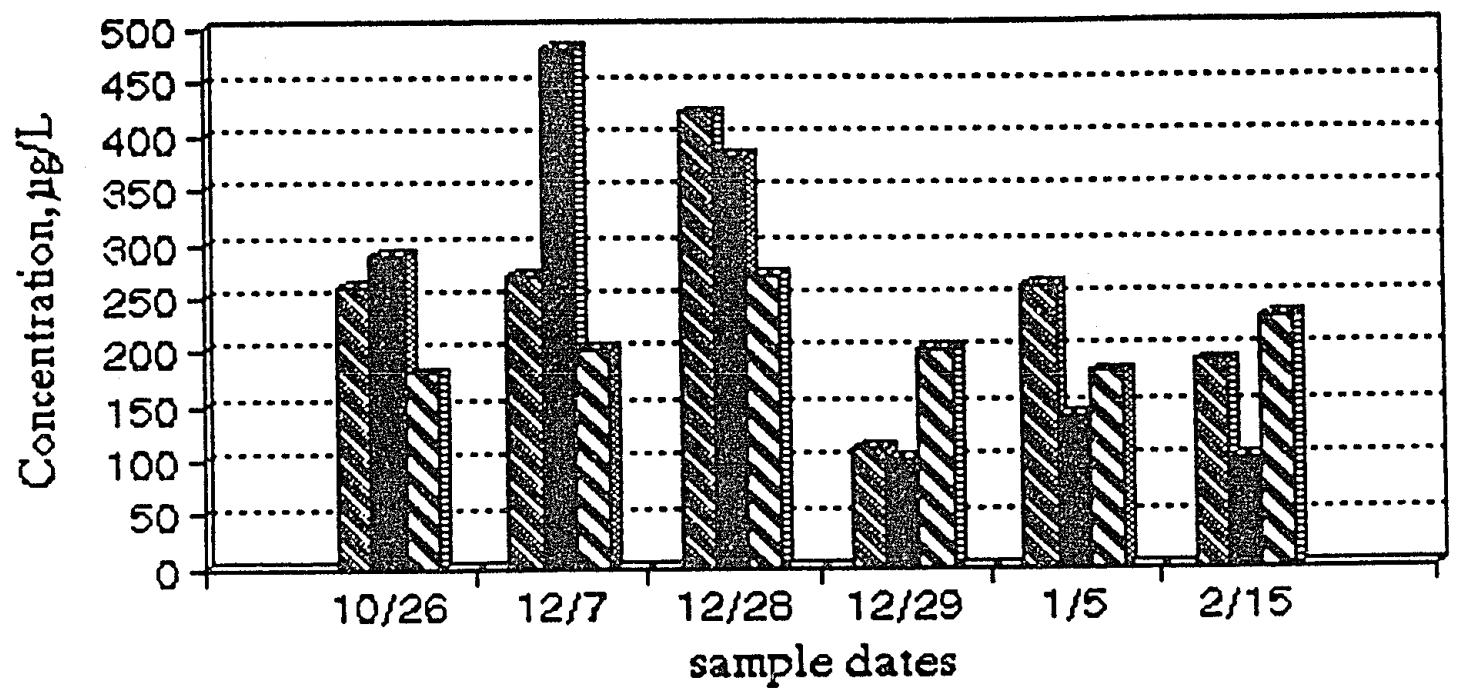

\section{Site S1 Site S3 Site S4}

Fig. 13.--Lead concentrations in $\mu \mathrm{g} / \mathrm{I}$ in San Francisquito Creek during storms

5. Discussion of the Lead Procedure

Dithizone $(\mathrm{HDz})$ is a weak acid insoluble in water and dilute acids below $\mathrm{pH} 7$, but dissolves in alkaline media, forming an orange solution of $\mathrm{HDz}$-anions. It reacts with lead to form a cherry-red chelate, which is soluble in chloroform, and can be extracted from neutral or alkaline media. Cyanide is used as a masking agent to complex interfering ions such as silver(I), copper(II), nickel(II), zinc(II), etc. Citrate solution added to the aqueous solution prevents the precipitation of ions of readily 
hydrolysed metals such as aluminum, iron and thallium (Marczenko 1986, 344).

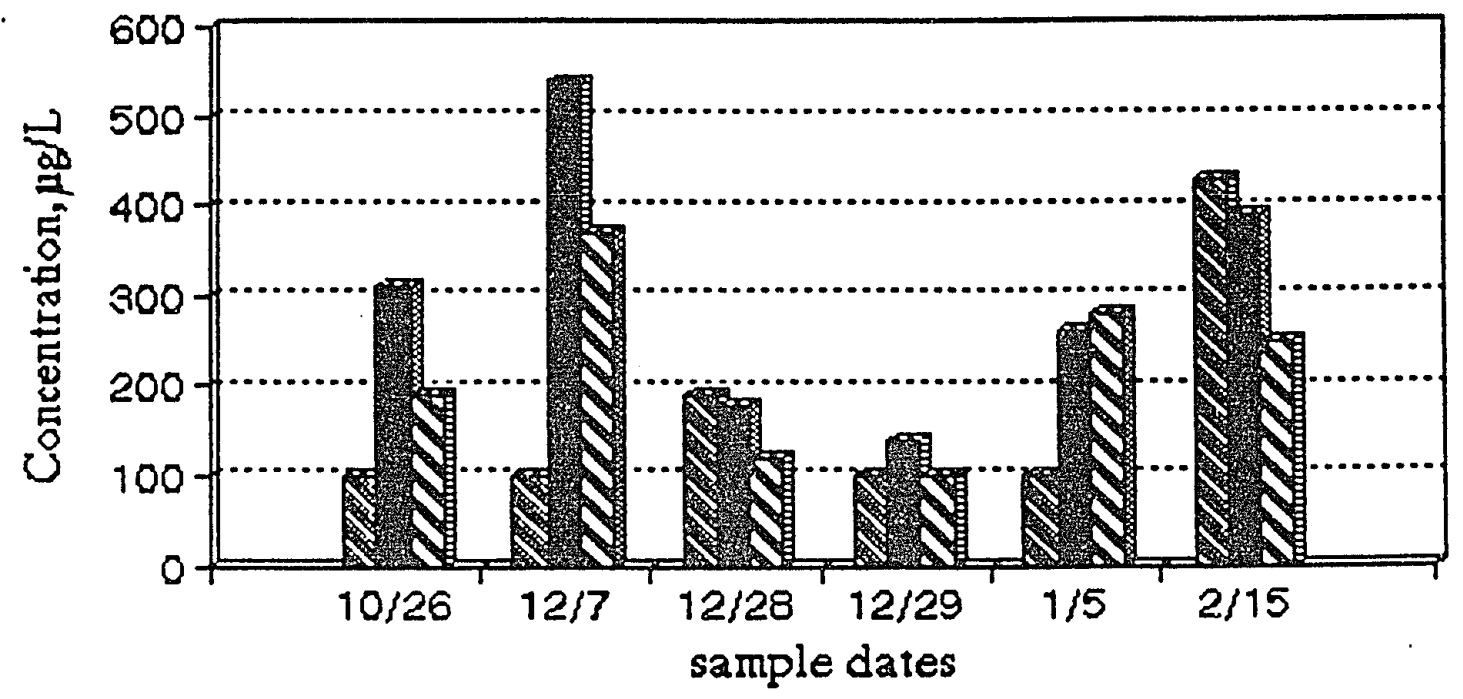

Site M1 Site A1 DIT Site A4

Fig. 14.--Lead concentrations in $\mu \mathrm{g} / \mathrm{I}$ in the Basin during storms

Due to the cumbersome nature of the procedure, the samples were analyzed in five different batches, each with its own calibration curve. For each curve, $5 \mu \mathrm{g}$ was used as the lowest point. With a $50.0 \mathrm{~mL}$ sample size, the $5 \mu \mathrm{g}$ lowest point was translated to $100 \mu \mathrm{g} / \mathrm{L}$ as the usable limit as shown in Equation 2:

$$
\frac{5 \mu \mathrm{g}}{50.0 \mathrm{~mL}} \times \frac{1000 \mathrm{~mL}}{1 \mathrm{~L}}=100 \mu \mathrm{g} / \mathrm{L}
$$


Even though the reference method recommended using 40 $\mu \mathrm{g}$ dithizone per $1 \mathrm{~mL}$ of chloroform, it was found by trial and error that $4 \mu \mathrm{g}$ of dithizone per $1 \mathrm{~mL}$ of chloroform gave satisfactory absorbance. The absorbance readings of the calibration curves among different batches were not very consistent. This was probably due to the aging of the intermediate dithizone solution. Generating a calibration curve for each batch of samples and preparing a new working solution minimized the bias.

Moreover, instead of three extractions, only one extraction was performed on each sample: This was due to the fact that the color was so unstable that it would fade within 1 minute. Therefore, the extraction was controlled by exactly 30 seconds of vigorous shaking on all samples, including the reagent blank, the standards, and the NPS samples.

Out of each batch, one sample was run in duplicate and/or spiked with a measured amount of standard solution to ensure measurement quality. From the four sets of duplicates, the precision range varied from 0.5 to $4.3 \mu \mathrm{g}$. From the three sets of standard additions, the accuracy recovery varied from 818 to 1268 . Appendix VI provides detailed quality control calculation. 


\section{Chapter V}

EVALUATION OF NPS DATA

\section{First Flush Effect}

At the time runoff commences from an impervious surface, there often are large quantities of loosely attached materials. These loosely bound and easily transported materials are usually incorporated largely into the initial part of the storm flow. This phenomenon is called the first flush effect. As observed by Griffin ot al., a plot of cumulative flow versus cumulative load for a single event is illustrated in Fig. 15 (Griffin, Randall, and Grizzard 1980, 1549).

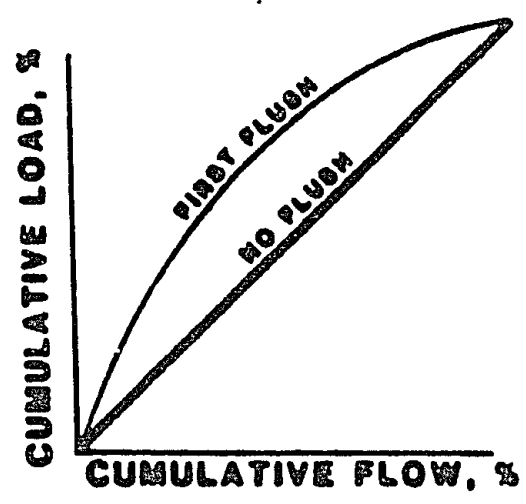

Fig. 15.-First flush phenomenon 
If the data shows a curve above the 45 degree no-flush line, first flush has occurred, because for a given fraction of the total flow, a greater fraction of the total load has been generated.

In order to see if first flush occurred in the Palo Alto runoff, two sets of samples were collected on two consecutive days, $12 / 28 / 92$ and $12 / 29 / 92$, with 0.51 and 1.39 inches of rainfall, respectively. Lack of flow information prevented calculation of actual load, but as shown in Tables 4 and 5 , for the first 308 of the rainfall, the reduction percent ( $8 \mathrm{Rd}$ ) in concentration on the two days averaged $>65 \%$ and $>438$ for copper and lead, respectively.

\begin{tabular}{||l|l|l|l|l|l|l|}
\hline & M1 & A1 & A4 & S1 & S3 & S4 \\
\hline $12 / 28$ & 79 & 74 & 150 & 100 & 71 & 71 \\
\hline $12 / 29$ & 29 & $<20$ & $<20$ & $<20$ & $<20$ & 62 \\
\hline 8 Rd & 63 & $>73$ & $>87$ & $>80$ & $>72$ & 13 \\
\hline
\end{tabular}

Table 4.--Percent reduction of $\mu \mathrm{g} / \mathrm{L}$ copper

A study done by the Northern Virginia Planning District Commission and Virginia Polytechnic Institute and State University found that capturing or removing approximately 
23 of the initial portion of the runoff flow would result in 658 removal of heavy metals (Randall, Grizzard and Hoehn $1978,18)$.

\begin{tabular}{||l|l|l|l|l|l|l||}
\hline & M1 & A1 & A4 & S1 & S3 & S4 \\
\hline $12 / 28$ & 190 & 180 & 120 & 420 & 380 & 270 \\
\hline $12 / 29$ & 100 & 140 & $<100$ & 110 & $<100$ & 200 \\
\hline 8 Rd & 47 & 22 & $>17$ & 74 & $>74$ & 26 \\
\hline
\end{tabular}

Table 5.--Percent reduction of $\mu \mathrm{g} / \mathrm{L}$ lead

Environmental Fate of Copper and Lead in Aguatic Systems

In this section, the discussion will be focused on the possible fate of copper and lead in the Flood Basin. In general, the lead level at $A 4$ (the outlet) is less than the levels at both $A 1$ and $M I$ (the inlets), although the level of copper does not follow this pattern too closely. In order to explain such decrease, one must understand the fate of various chemicals in an aquatic system.

As discussed in the Water-Related Environmental Fate of 129 Priority Pollutants from the Environmental Protection Agency (EPA), there are several physical, chemical, and biological processes that affect the concentration of a 
chemical in an aquatic system. Physical processes include volatilization and sorption. Chemical processes include photolysis, hydration, oxidation, reduction and hydrolysis. Biological processes include bioaccumulation, biotransformation and biodegradation (Callahan et al. 1979, vol $1,2: 1-15)$.

In particular, the EPA found that the dominant fate of copper in an aquatic environment includes complex formation, especially with humic substances, bioaccumulation, and sorption on hydrous metal oxides, clays and organic materials. In addition, once complexed, copper is more easily adsorbed by clays and other surfaces. Thus, in polluted water, sorption of copper is a major removal pathway. It is also strongly bioaccumulated but biomagnification is insignificant (Callahan et al. 1979, vol 1 $11: 1-16)$.

For lead, the EPA reported that sorption processes are effective in reducing the concentration of soluble lead and result in enrichment of bed sediment near the sources. The tendency for lead to form complexes with organic materials increases its adsorptive affinity for clays and other mineral surfaces. In addition, benthic microbes can methylate lead to form tetramethyl lead $\left(\left(\mathrm{CH}_{3}\right)_{4}\right) \mathrm{Pb}$, which is volatile and more toxic than inorganic lead. Lead bioaccumulates but biomagnification is insignificant (Callahan 
et al. 1979, vol 1 13:1-16).

since it is generally true that sorption is the predominant removal pathway for heavy metals, the decrease of copper and lead concentrations on the outlet is understandable as some of the pollutants may have sorbed onto the clay bed of the Basin. However, without a detailed study of total loading in the water, the soil, the vegetation and the runoff flow, no quantifiable data can be obtained.

There could be a second reason for such decrease. As indicated in Chapter I, the water level of the Basin is kept below sea level, controlled by the flood gate located at A4. The flushing by Bay water acts to dilute the pollutants. According to a study done by Woodward-Clyde Consultants, the concentrations of copper and lead in the water around that area (Station SB5) in the wet season were 6 and $1 \mu \mathrm{g} / \mathrm{I}$ respectively in 1990 (Woodward-Clyde Consultants 1991, Fig E-6 and Fig. E-5). A conclusion that 1 to 100 dilution occurs cannot be drawn, however, due to the settleability and the wind effect as discussed later.

\section{Plume Travel}

The samples collected for the study were grab samples which could only represent the composition of the sources at that particular time and place. It was possible that the 
pollutants plume traveled beyond the preceding sample site but was caught at the following site. Although theoretically A4 should not have had such a high copper concentration on $12 / 28,1 / 5$ and $2 / 15$, or of lead on $1 / 5$, it would seem that the actual pollutant plume passed through the previous sample points and was caught at A4.

\section{Wind Effect}

The other reason for the higher A4 outlet value is because as the wind blows stronger in a storm, it creates stronger waves in the water. The waves, in turn, bring up the pollutants, including the material containing copper and lead, from the bed of the Basin. To worsen the situation, as shown in Fig. 16, there is no vegetation to cover the soil in the outlet area. As a result, wind cannot be slowed down and pollutants are more likely to be resuspended.

\section{Bay Intrusion}

All sample sites are intruded on by the Bay water to some extent. As stated in Section $C$ of this Chapter, the study from Woodward-Clyde Consultants found that the concentrations of copper and lead in the Bay were approximately 6 and $1 \mu \mathrm{g} / \mathrm{L}$, respectively. Since the concentration values obtained during this study are much higher than that of the Bay, it can be concluded that most 
of the pollutants were from the runoff and not from the Bay.

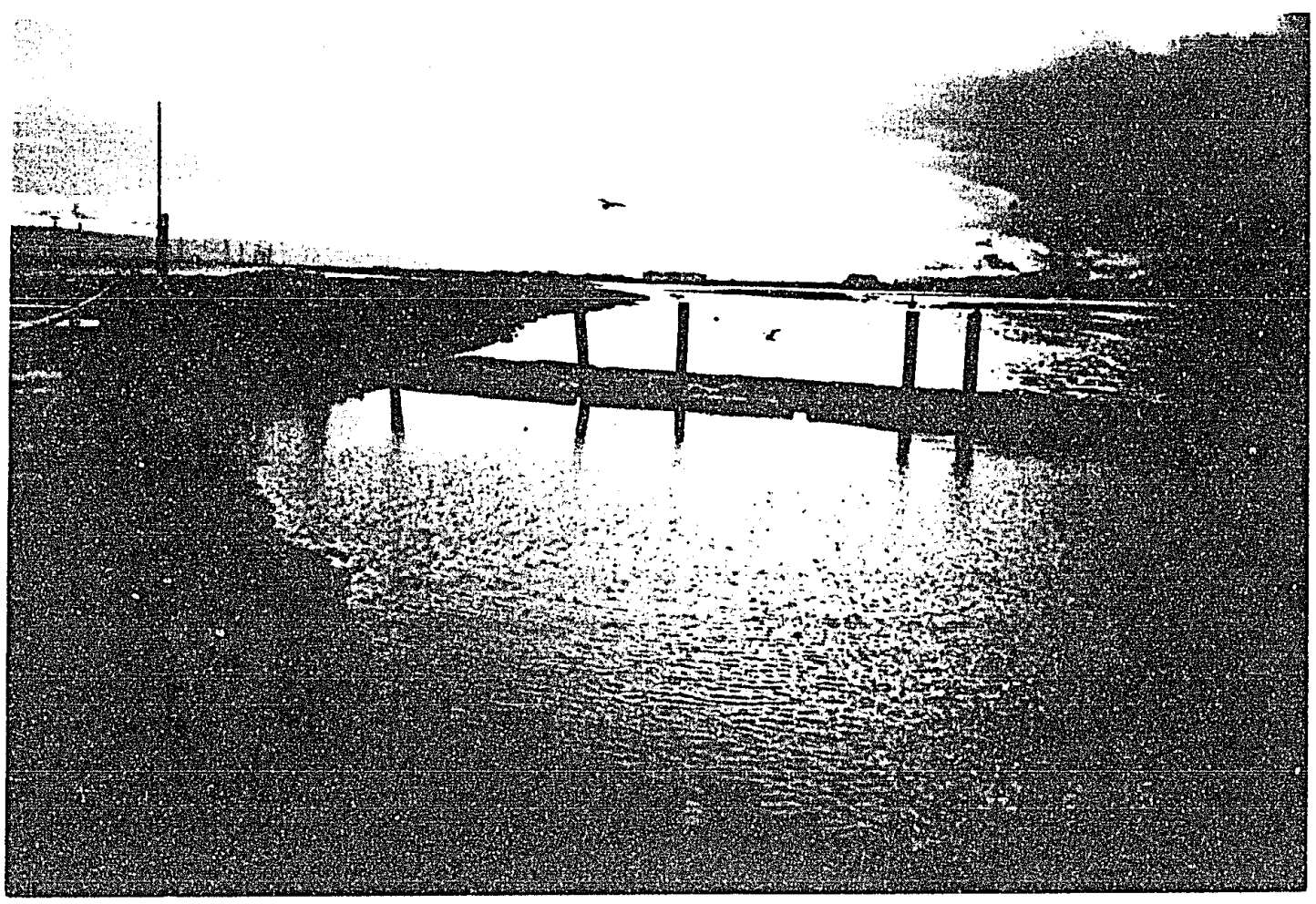

Fig. 16.--Areas around the flood gate

\section{Mass Balance}

As indicated by Woodward-Clyde Consultants, the background sediment concentrations of copper and lead were 50 and $25 \mu \mathrm{g} / \mathrm{g}$ respectively at Station SB5 (Woodward-Clyde Consultants 1991, Fig E-8 and Fig. E-9). The scope of this study was limited to the concentrations of the copper and lead in the surface water. However, in order to obtain a mass balance of the pollutants, it is necessary to consider the concentrations of copper and lead in the sediment. Thus 
pollutants concentrations in the sediment would be a subject of a future investigation.

\section{Regional Effort}

As mentioned in Chapter I, the Board has directed Santa Clara County to tackle the NPS problems. However, such a county-type division does not adequately address a problem that spans more than one county. Location $\mathbf{S 4}$ is downstream of a discharge pump station that collects the runoff from certain parts of East Palo Alto, which is in San Mateo County. As demonstrated by the data on $2 / 15 / 92$, when a sample was collected during East Palo Alto runoff discharging, the metal concentrations were higher than those from the previous two sample sites. In order to solve the NPS pollution problems, it is important to call for a regional approach. 


\section{Chapter VI}

CONSTRUCTED WETLANDS

To protect the estuary of the Bay, it is necessary to reduce the pollutant loading of the NPS discharge. One option is to connect the NPS discharge to the RWQCP for conventional treatment; another option is to construct wetlands to treat the water. However, the former option is not feasible because the wet weather peak treatment capacity of the RWQCP is $80 \mathrm{MGD}$, and with a wet season peak flow of 60 MGD, the RWQCP cannot receive much additional flow during storms. The latter option is preferable because wetlands can, as discussed below, improve water quality by trapping pollutants internally. The purpose of this chapter is then to focus on the feasibility of constructing fresh water wetlands to meet this goal.

\section{Definition of Wetlands}

Wetlands, as recognized by the U.S. Fish and Wildlife Service, are lands transitional between terrestrial and aquatic systems. Water is the dominant factor determining development of soils and associated biological communities. At least periodically, the water table is at or near the 
surface, or the land is covered by shallow water. Wetlands must meet one or more of three conditions (Cowardin et al. $1979,3):$

- areas supporting predominantly hydrophytes (at least periodically)

- areas with predominantly undrained hydric soil (wet enough for long enough period to produce anaerobic conditions that limit the types of plants that can grow there)

- areas with nonsoil substrate (such as rock or gravel) that are saturated or covered by shallow water at some time during the growing season

\section{Function of Wetlands}

The main function of wetlands in nature is to receive, hold, and recycle nutrients continually washed from upland regions and, directly or indirectly, convert inorganic chemicals into the organic materials required in the food chain. Being an ecotone, wetlands are the habitat of zooplankton, worms, insects, crustaceans, reptiles, amphibians, fish, birds, and mammals. This community, in turn, attracts other animals from greater distances, thus extending its productive influence beyond its border. Wetlands can also improve water quality by providing natural filtration, sedimentation, and other processes to 
help clear the water of many pollutants. Some pollutants are physically or chemically immobilized and remain there permanently unless disturbed. Chemical reactions and biological decomposition break down complex compounds into simple substances. Through absorption and assimilation, wetlands plants remove nutrients for biomass production. Oxygen, a by-product of the plant growth process, increases dissolved oxygen (DO) content in the water and the soil in the immediate vicinity of plant roots. The increased DO in turn elevates the capacity of the system for aerobic bacterial decomposition of pollutants as well as the capacity for supporting a wide range of aerobic aquatic organisms, some of which directly or indirectly utilize additional pollutants. Vegetation is also crucial to slow down the wind and hold the pollutants undisturbed.

Moreover, wetlands can also offer attractive amenities to the community by providing open space, recreation, waterfront property, and educational opportunities for every member of society.

The Demonstration of Urban Stormwater Treatment (DUST) Marsh in Fremont across the Bay serves as a good example. These wetlands cover about 55 acres with three subsystems to treat urban runoff. In the final report of Urban Stormwater Treatment at Coyote Hills Marsh, the trap efficiency for suspended constituents was 42-458 for solids, 30-838 for 
lead, 40-458 for chromium, 12-348 for nickel, 6-518 for zinc and 5-328 for copper, depending on the systems applied (Meiorin 1986, 76). The marsh is also part of the coyote Hill Regional Park that provides beneficial wildlife habitat and attractive amenities to the community. In addition to open space, nature trails and picnic areas, there is an visitor center that provides knowledge about nature, particularly wetlands.

Feasibility of Constructing Fresh Water Wetlands at the Palo Alto Flood Basin

Currently, the Palo Alto Flood Basin collects all the pollutants from urban runoff without any control. The idea is to construct multi-purpose fresh water wetlands within the Basin to treat the pollutants and meet all other criteria. In dry seasons or during drought years, the nearby RWQCP could provide reclaimed water to sustain necessary life in the wetlands. In wet seasons, the storm water from Matadero Creek and Adobe Creek would flow through the wetlands before releasing to the Basin and later to the Bay.

This concept is feasible for several reasons. First, the runoff from the storm is treatable. The Environmental Compliance Division of the City began collecting stormwater runoff samples from the four major creeks in 1992. Although 
the sites were upstream from the sample sites of this study, laboratory metal data indicated that, as shown in Tables 6 and 7, while some of the pollutants are present in high enough concentrations to damage the Bay, the runoff contains typical urban runoff not toxic enough to damage the marsh and wildlife. Selenium (Se), an element responsible for the catastrophe at the Kesterson evaporation ponds, is present only in very low concentrations (City of Palo Alto 1992). Second, the land is currently available for wetlands use. As stated in Chapter $I$, the Basin itself consists of 600 acres of marshlands. Thus, the wetlands can be redeveloped close to the area where the two creeks enter the Basin. By means of a dike the constructed wetlands can be sectioned off from the rest of the Basin.

Third, there is an abundance of fresh water available. The high quality reclaimed water from the nearby RWQCP can be utilized. Under the regulation of the EPA and the Board, the RWQCP monitors the reclaimed water constantly. The existing ITT marsh, for example, is approved by the Board to apply reclaimed water to benefit wildlife. Existing data from the City indicates that the water quality of the ITT Marsh remains within the expected levels. For example, copper and lead concentrations range from $18-30$ and $1-7 \mu \mathrm{g} / \mathrm{L}$ respectively (City of Palo Alto 1992). With the more stringent Bay Basin Plan and continuous effort to lower 
discharge limit, the quality of the reclaimed water is expected to inprove.

\begin{tabular}{|l|l|l|l|l|}
\hline & Mata. & Barron & Adobe & San Fran. \\
\hline $\mathrm{Ag}$ & $<0.2$ & 11.1 & $<0.2$ & $<0.2$ \\
\hline $\mathrm{As}$ & 3 & 6 & 3 & 2 \\
\hline $\mathrm{Cd}$ & $<1$ & 1 & 1 & $<1$ \\
\hline $\mathrm{Cr}$ & 18 & 29 & 15 & 4 \\
\hline $\mathrm{Cu}$ & 42 & 73 & 41 & 13 \\
\hline $\mathrm{Hg}$ & 0.3 & 0.4 & 0.2 & $<0.1$ \\
\hline $\mathrm{Ni}$ & 22 & 30 & 18 & 7 \\
\hline $\mathrm{Pb}$ & 57 & 290 & 40 & 6 \\
\hline $\mathrm{Se}$ & 1 & $<1$ & $<1$ & $<1$ \\
\hline $\mathrm{Zn}$ & 199 & 288 & 174 & 57 \\
\hline \hline
\end{tabular}

Table 6.--Metal pollutants concentrations in $\mu \mathrm{g} / \mathrm{I}$ of runoff from the four major creeks in the Palo Alto Area on Oct. 29, 1992

Lastly, the vegetation is already established. The existing cattail, bulrush, sedge, tule, etc. are desirable growth. Therefore, native plants can be used instead of 
foreign plants that may pose a negative impact on the existing ecosystem.

\begin{tabular}{|l|l|l|l|l||}
\hline & Mata. & Barron & Adobe & San Fran. \\
\hline $\mathrm{Ag}$ & 0.7 & $<0.2$ & $<0.2$ & $<0.2$ \\
\hline $\mathrm{As}$ & 2 & 1 & 1 & 1 \\
\hline $\mathrm{Cd}$ & 0.8 & 0.4 & 0.4 & 0.9 \\
\hline $\mathrm{Cr}$ & 20 & 7 & 5 & 7 \\
\hline $\mathrm{Cu}$ & 47 & 24 & 20 & 21 \\
\hline $\mathrm{Hg}$ & 0.4 & $<0.1$ & 0.1 & 0.8 \\
\hline $\mathrm{Ni}$ & 26 & 7 & 8 & 12 \\
\hline $\mathrm{Pb}$ & 54 & 11 & 19 & 15 \\
\hline $\mathrm{Se}$ & $<0.4$ & $<0.4$ & 0.5 & $<0.4$ \\
\hline $\mathrm{Zn}$ & 234 & 67 & 124 & 78 \\
\hline
\end{tabular}

Table 7.--Metal pollutants concentrations in $\mu \mathrm{g} / \mathrm{L}$ of runoff from the four major creeks in the Palo Alto area on Dec. 28, 1992

Guidelines for Constructing Fresh Water Wetlands It is beyond the scope of this thesis to consider the engineering design of the wetlands, but several guidelines 
should be observed:

1. Design

The wetlands should act to enhance the function of the Flood Basin. Thus the design should not impair the retention capacity or alter the water layer of the Flood Basin.

2. Site

The site should be able to receive the runoff from both Matadero Creek and Adobe Creek and should not be too far away from the RWQCP so that a cost-effective pipeline to transport the reclaimed water may be built.

3. Area

The designated area should be large enough to treat a specified storm water volume. The DUST Marsh, for example, is designed to divert runoff volumes up to $490 \mathrm{cu}-\mathrm{ft} / \mathrm{s}$, which is equivalent to the peak flow of a 10-year storm. 4. Water

The water level should meet a predetermined level so that sufficient water is available to sustain life. 5. Configuration

Configuration may be a single cell, parallel cells, series (longitudinal or serpentine) cells, or any combination of cells and ponds. A combination of different types could be used to maximize edging. Also, a length to width ratio $(\mathrm{L} / \mathrm{W})$ of at least 10 is recommended for the 
surface flow system to maximize pollutants uptake (Steiner and Freeman 1989, 370).

6. Slope

For drainage and maintenance, a slope of 0.58 or less is recommended for surface flow system to establish gravity flow without releasing the runoff too quickly in order to optimize removal rate of pollutants (Steiner and Freeman $1989,371)$

7. Valves and Pumps

Automatic control valves should be installed in both the inlets of the reclaimed water and the storm water in order to balance the water level of the wetlands. An additional bypassing valve should also be positioned in case of a catastrophic storm. In such a case, the first portion of the runoff could still pass through the constructed wetlands for treatment, but the remaining portion could be discharged directly to the Basin. An emergency shut off valve should be installed at the reclaimed water inlet to protect the wetlands from damage if there is an upset of the treatment system of the RWQCP. Moreover, pumps should be installed in proper locations within the wetlands so that certain cells may be emptied for maintenance or harvesting. 8. Vegetation

Original vegetation from the Basin should be used in the new wetlands. The existing cattail, bulrush, sedge, 
tule, etc. are desirable; however, the ratio of each species should be predetermined and planted according to each growing season. Other species may be introduced only after thorough study to ensure that there is no negative environmental impact.

\section{Soil}

Original soil from the site should be saved to be reused in the new wetlands. Different littoral zones should be designed for different species. Dry land areas and islands should be designed to increase resting zones for wildlife.

\section{Aesthetic amenities}

Some nature trails and observation sites should be designed for the public. Care should be taken that pedestrian paths do not disturb the habitat of the wildlife. Natural fences should be used instead of wire fences. Iight and noise control should also be established.

11. Other

Other concerns such as mosquito control, pathogen prevention and a general maintenance schedule should be well planned and properly managed under the authorized department. 
Chapter VII

CONCLUSION

Nonpoint source discharge samples collected from the three major creeks of the Palo Alto area in the rainy season of 1991-1992 showed that pollutants on street surfaces were washed off to the San Francisco Bay at an elevated level as indicated by the study of copper and lead concentrations. While the concentrations of both elements could be several times higher than that of the Bay, especially during the first portion of a storm, it was found that after initial washoff from the rain, the pollutants were reduced by more than half. Constructing fresh water wetlands would provide a means to trap some of the pollutants by proper design and continuous maintenance. Since long term studies of bioaccumulation and biomagnification of various pollutants at existing constructed wetlands are limited, the wetlands should be closely monitored and periodically re-evaluated. Despite its advantages, a constructed wetlands only provides an "end-of-pipe" solution to the NPS discharge problem. To provide a complete solution, source control, such as eliminating illicit sewage connections and preventing illegal dumping, should be regionally enforced. 
Community programs, such as curb-side pick up, recycling programs, and hazardous materials drop-off days should be implemented and widely publicized. Measures to mitigate traffic flow should be encouraged by industry and the city. Moreover, streets should be swept frequently and obstructions in creeks should be cleared regularly to ensure free flow. Last, but not least, public education remains an important factor to influence people to behave responsibly and sensitively to the environment. 


\section{Appendix I}

RAINFALI RECORD IN THE PALO ALTO AREA

The following rainfall record was obtained from the Official Weather Observer's Record at Palo Alto Fire station (US Department of Commerce 1991-1992).

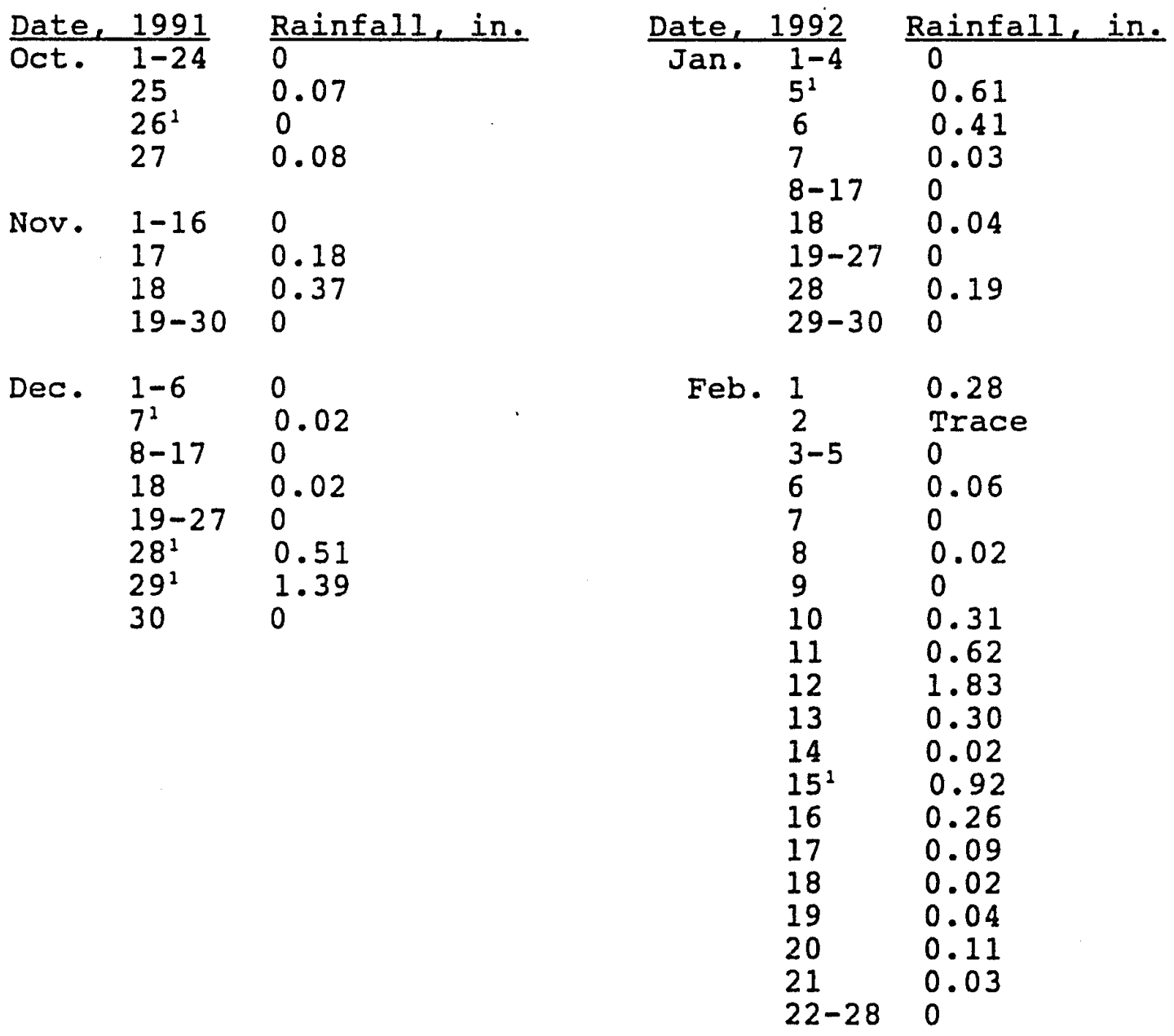

${ }^{1}$ Sample date 
Appendix II

CAIIBRATION AND CAICULATION OF THE COPPER CONCENTRATIONS

A Quattro Pro spreadsheet was used to calculate a best fit curve of absorbance versus $\mu g$ of copper standards for a calibration curve and subsequently used to calculate the $\mu \mathrm{g}$ of copper in the $50.0 \mathrm{~mL}$ sample. Final values were reported to two significant figures with calibration limit of $20 \mu \mathrm{g} / \mathrm{L}$.

One sample from each batch was chosen randomly to run in duplicate. That particular sample was labeled as (1) and (2) following the sample identification (ID). The final reported value was the average of the duplicates.

When the method of standard addition was applied, the particular sample was labeled as the actual percentage of the NPS sample taken, plus the $\mu \mathrm{g}$ of standard added.

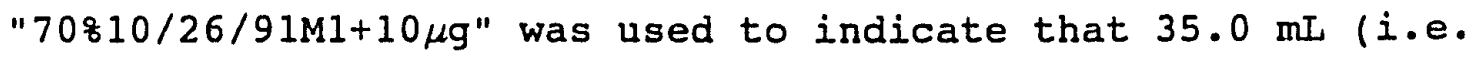
$70 \%$ of $50.0 \mathrm{~mL}$ ) of sample ID 10/26/91MI was mixed with $10 \mu \mathrm{g}$ of standard creating a solution which was then brought to a final volume of $50.0 \mathrm{~mL}$ with distilled water.

The samples were analyzed in two batches, each with its own calibration curve. Calibration curves and calculation of sample concentrations are as follows: 


\section{Sample Batch One}

1. Calibration curve, $10 / 31 / 92$

The first batch was analyzed on 10/31/92. Absorbance data is Iisted as below along with regression analysis to give the best fit straight line as shown in Fig. 17.

$\begin{array}{rl}\mu \mathrm{g} & \text { Abs. } \\ 0.0 & 0.0000 \\ 1.0 & 0.0036 \\ 5.0 & 0.0171 \\ 10.0 & 0.0354\end{array}$

Regression Output Y-intercept $-8.5 \mathrm{E}-05$ Std Err of $Y$ Est 0.00037 $R$ Squared 0.99964 No. of Observations 4 $\begin{array}{lr}\text { Degree of Freedom } & 2 \\ \text { Slope } & 0.00353\end{array}$ 0.00353
$4.8 \mathrm{E}-05$

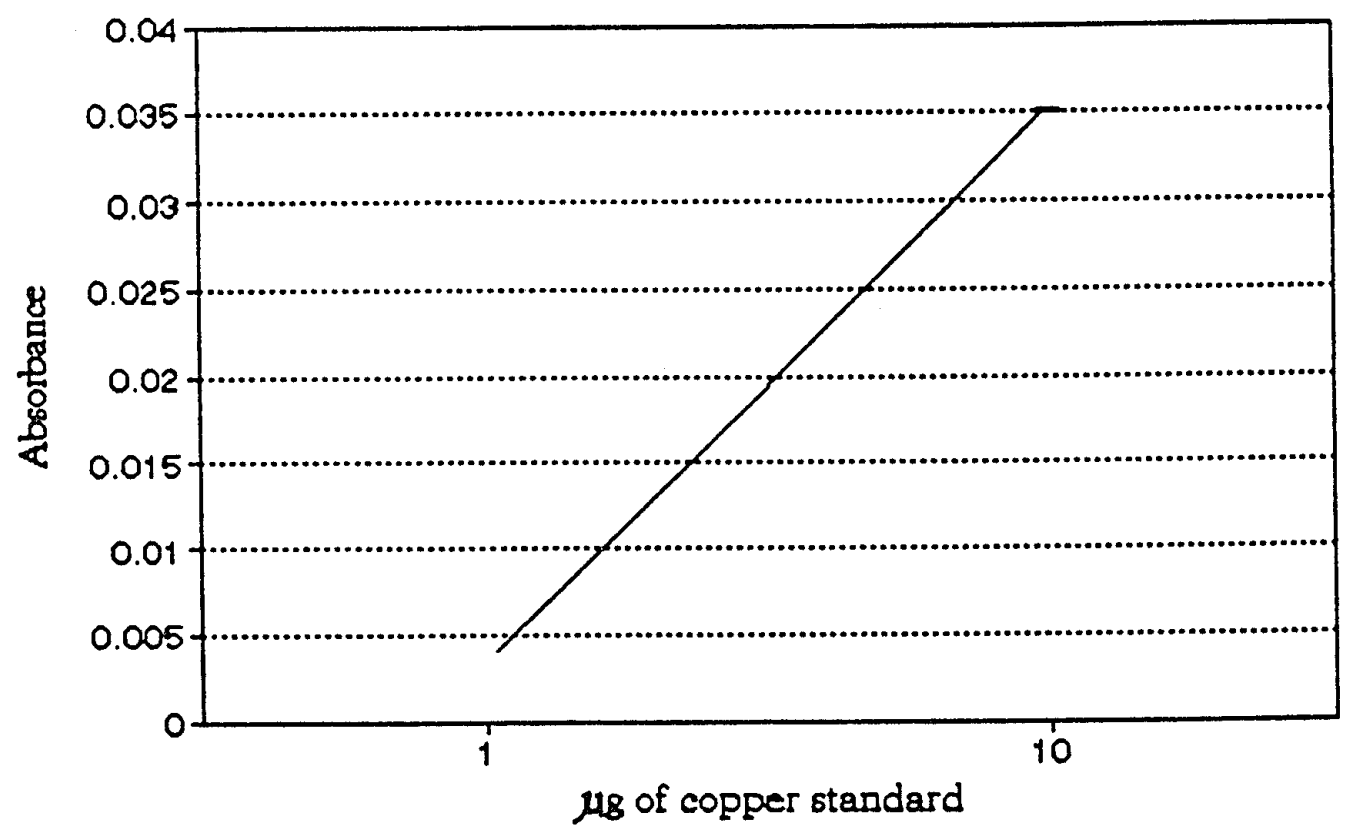

Fig. 17.--Copper calibration curve, 10/31/92 
2. Sample analysis

\begin{tabular}{|c|c|c|c|}
\hline $\begin{array}{l}\text { Sample ID } \\
10 / 26 / 91 \mathrm{M} 1(1) \\
10 / 26 / 91 \mathrm{MI}(2) \\
70810 / 26 / 91 \mathrm{M} 1+10 \mu \mathrm{g} \\
10 / 26 / 91 \mathrm{~A} 1 \\
10 / 26 / 91 \mathrm{~A} 4 \\
10 / 26 / 91 \mathrm{~S} 1 \\
10 / 26 / 91 \mathrm{~S} 3 \\
10 / 26 / 91 \mathrm{~S} 4 \\
12 / 7 / 91 \mathrm{M} 1 \\
12 / 7 / 91 \mathrm{Al} \\
12 / 7 / 91 \mathrm{~A} 4 \\
12 / 7 / 91 \mathrm{~S} 1 \\
12 / 7 / 91 \mathrm{~S} 3 \\
12 / 7 / 9154 \\
12 / 28 / 91 \mathrm{M} 1 \\
12 / 28 / 91 \mathrm{~A} 1 \\
12 / 28 / 91 \mathrm{~A} 4 \\
12 / 28 / 91 \mathrm{~S} 1 \\
12 / 28 / 91 \mathrm{~S} 3 \\
12 / 28 / 91 \mathrm{~S} 4\end{array}$ & $\begin{array}{l}\text { Abs. } \\
0.0121 \\
0.0100 \\
0.0392 \\
0.0141 \\
0.0096 \\
0.0154 \\
0.0230 \\
0.0170 \\
0.0093 \\
0.0279 \\
0.0111 \\
0.0114 \\
0.0107 \\
0.0081 \\
0.0138 \\
0.0129 \\
0.0272 \\
0.0184 \\
0.0124 \\
0.0125\end{array}$ & $\begin{array}{r}\frac{\mu \mathrm{q}}{3.45} \\
2.86 \\
11.14 \\
4.02 \\
2.75 \\
4.39 \\
6.55 \\
4.84 \\
2.66 \\
7.93 \\
3.17 \\
3.26 \\
3.06 \\
2.32 \\
3.94 \\
3.68 \\
7.74 \\
5.24 \\
3.54 \\
3.57\end{array}$ & $\begin{array}{r}\mu \mathrm{g} / \mathrm{L} \\
69 \\
57 \\
220 \\
80 \\
55 \\
88 \\
130 \\
97 \\
53 \\
160 \\
63 \\
65 \\
61 \\
46 \\
79 \\
74 \\
150 \\
100 \\
71 \\
71\end{array}$ \\
\hline
\end{tabular}

Sample Batch Two

1. Calibration curve, $11 / 15 / 92$

The second batch was analyzed on $11 / 15 / 92$. Absorbance data is listed as below in the same manner as in batch one. The best fit line is shown in Fig. 18 .

$\begin{array}{rl}\frac{\mu \mathrm{g}}{0.0} & \text { Abs. } \\ 1.0 & 0.0000 \\ 5.0 & 0.0036 \\ 10.0 & 0.0202 \\ 20.0 & 0.0365 \\ & 0.0668\end{array}$

Regression Output:

$\begin{array}{lr}\text { Y-intercept } & 0.00139 \\ \text { Std Err of Y Est } & 0.00204 \\ \text { R Squared } & 0.99581 \\ \text { No. of Observation } & 5 \\ \text { Degree of Freedom } & 3 \\ \text { Slope } & 0.00334 \\ \text { Std Err of Slope } & 0.00013\end{array}$




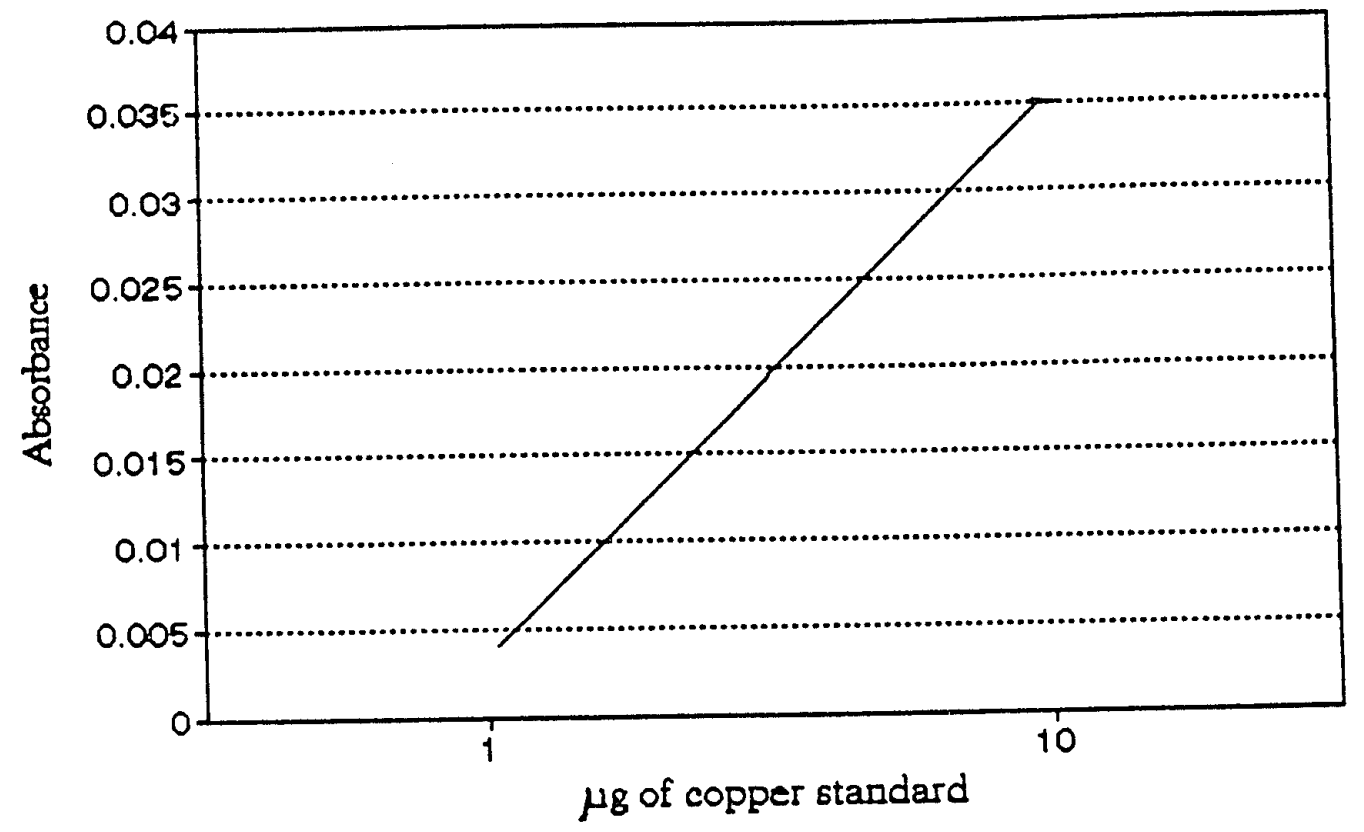

Fig. 18.--Copper calibration curve, 11/15/92

2. Samples analysis

\begin{tabular}{|c|c|c|c|}
\hline $\begin{array}{l}\text { Sample ID } \\
12 / 29 / 91 \mathrm{M} 1 \\
12 / 29 / 91 \mathrm{Al} \\
12 / 29 / 91 \mathrm{~A} 4 \\
12 / 29 / 91 \mathrm{~S} 1 \\
12 / 29 / 91 \mathrm{~S} 3 \\
12 / 29 / 91 \mathrm{~S} 4 \\
1 / 5 / 91 \mathrm{M} 1 \\
1 / 5 / 91 \mathrm{~A} 1(1) \\
1 / 5 / 91 \mathrm{~A} 1(2) \\
7081 / 5 / 91 \mathrm{~A} 1+5 \mu \mathrm{g} \\
1 / 5 / 91 \mathrm{~A} 4 \\
1 / 5 / 91 \mathrm{~S} 1 \\
1 / 5 / 9153 \\
1 / 5 / 91 \mathrm{~S} 4 \\
2 / 15 / 91 \mathrm{M} 1 \\
2 / 15 / 91 \mathrm{~A} 1 \\
2 / 15 / 91 \mathrm{~A} 4 \\
2 / 15 / 91 \mathrm{~S} 1 \\
2 / 15 / 91 \mathrm{~S} 3 \\
2 / 15 / 91 \mathrm{~S} 4\end{array}$ & $\begin{array}{l}\text { Abs. } \\
0.0063 \\
0.0041 \\
0.0026 \\
0.0046 \\
0.0019 \\
0.0118 \\
0.0105 \\
0.0026 \\
0.0017 \\
0.0214 \\
0.0062 \\
0.0040 \\
0.0132 \\
0.0098 \\
0.0068 \\
0.0065 \\
0.0172 \\
0.0070 \\
0.0066 \\
0.0090\end{array}$ & $\begin{array}{l}\mu \mathrm{g} \\
1.47 \\
0.81 \\
0.36 \\
0.96 \\
0.15 \\
3.12 \\
2.73 \\
0.36 \\
0.09 \\
5.99 \\
1.44 \\
0.78 \\
3.54 \\
2.52 \\
1.62 \\
1.53 \\
4.73 \\
1.68 \\
1.56 \\
2.28\end{array}$ & $\begin{array}{r}\frac{\mu g / I}{29} \\
<20 \\
<20 \\
<20 \\
<20 \\
62 \\
55 \\
<20 \\
<20 \\
120 \\
29 \\
<20 \\
71 \\
50 \\
32 \\
31 \\
95 \\
34 \\
46 \\
71\end{array}$ \\
\hline
\end{tabular}




\section{Appendix III \\ CALIBRATION AND CALCULATION OF THE LEAD CONCENTRATIONS}

The calibration and calculation of lead concentrations were done in the same manner as for copper. Final values were reported to two significant figures with a calibration limit of $100 \mu \mathrm{g} / \mathrm{I}$.

The samples were analyzed in five batches, each with its own calibration curve. Calibration curves and the calculation of sample concentrations are as follows:

\section{Sample Batch One}

1. Calibration curve, 5/21/92 AM

The first batch was analyzed in the morning of 5/21/92. Absorbance data is listed as below along with regression analysis to give the best fit straight line as showm in Fig. 19 .

$\begin{array}{rl}\frac{\mu \mathrm{g}}{0.0} & \text { Abs. } \\ 5.0 & 0.0000 \\ 10.0 & 0.0634\end{array}$

$\begin{array}{lr}\text { Regression Output: } & \\ \text { Y-intercept } & 0.0021 \\ \text { Std Err of Y Est } & 0.00514 \\ \text { R Squared } & 0.99596 \\ \text { No. of Observation } & 3 \\ \text { Degree of Freedom } & 1 \\ \text { Slope } & 0.01142 \\ \text { Std Err of Slope } & 0.00073\end{array}$




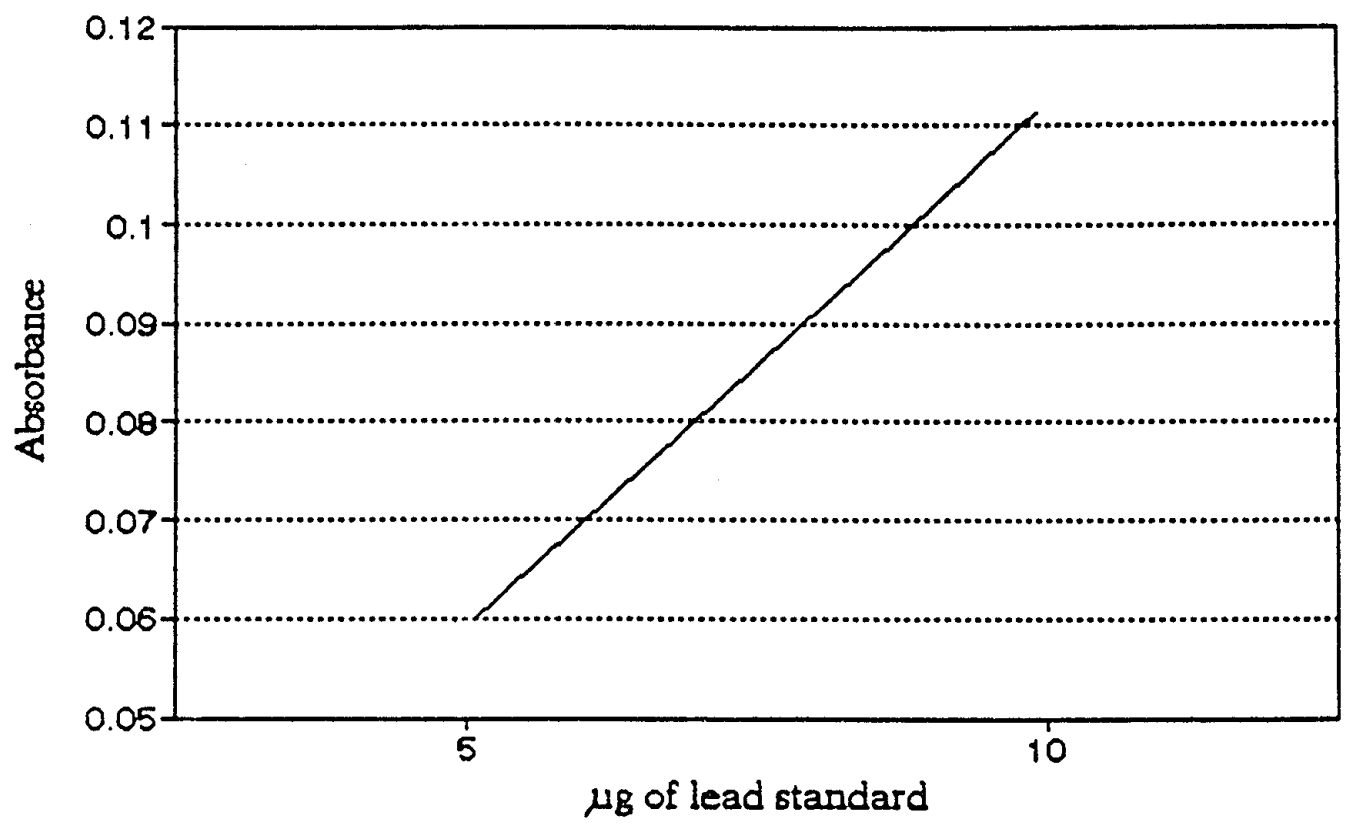

Fig. 19.--Lead calibration curve, 5/21/92 AM

2. Sample analysis

\begin{tabular}{llrl} 
Sample ID & Abs. & $\mu \mathrm{g}$ & $\mu \mathrm{g} / \mathrm{L}$ \\
\hline $10 / 26 / 91 S 4$ & 0.1056 & 9.06 & 180 \\
$70810 / 26 / 9154+10 \mu \mathrm{g}$ & 0.1641 & 14.19 & 280
\end{tabular}

\section{Sample Batch Two}

1. Calibration Curve, 5/21/92 PM

The second batch was analyzed in the afternoon of

5/21/92. Absorbance data is listed as below in the same manner as in batch one. The best-fit calibration curve is shown in Fig. 20 .

$\begin{array}{rl}\frac{\mu \mathrm{g}}{0.0} & \text { Abs. } \\ 5.0 & 0.0000 \\ 10.0 & 0.0192\end{array}$

$\begin{array}{lr}\text { Regression Output } & \\ \text { Y-intercept } & -0.0018 \\ \text { Std Err of Y Est } & 0.00441 \\ \text { R Squared } & 0.98419 \\ \text { No. of Observations } & 3 \\ \text { Degree of Freedom } & 1 \\ \text { Slope } & 0.00492 \\ \text { Std Err of Slope } & 0.00062\end{array}$




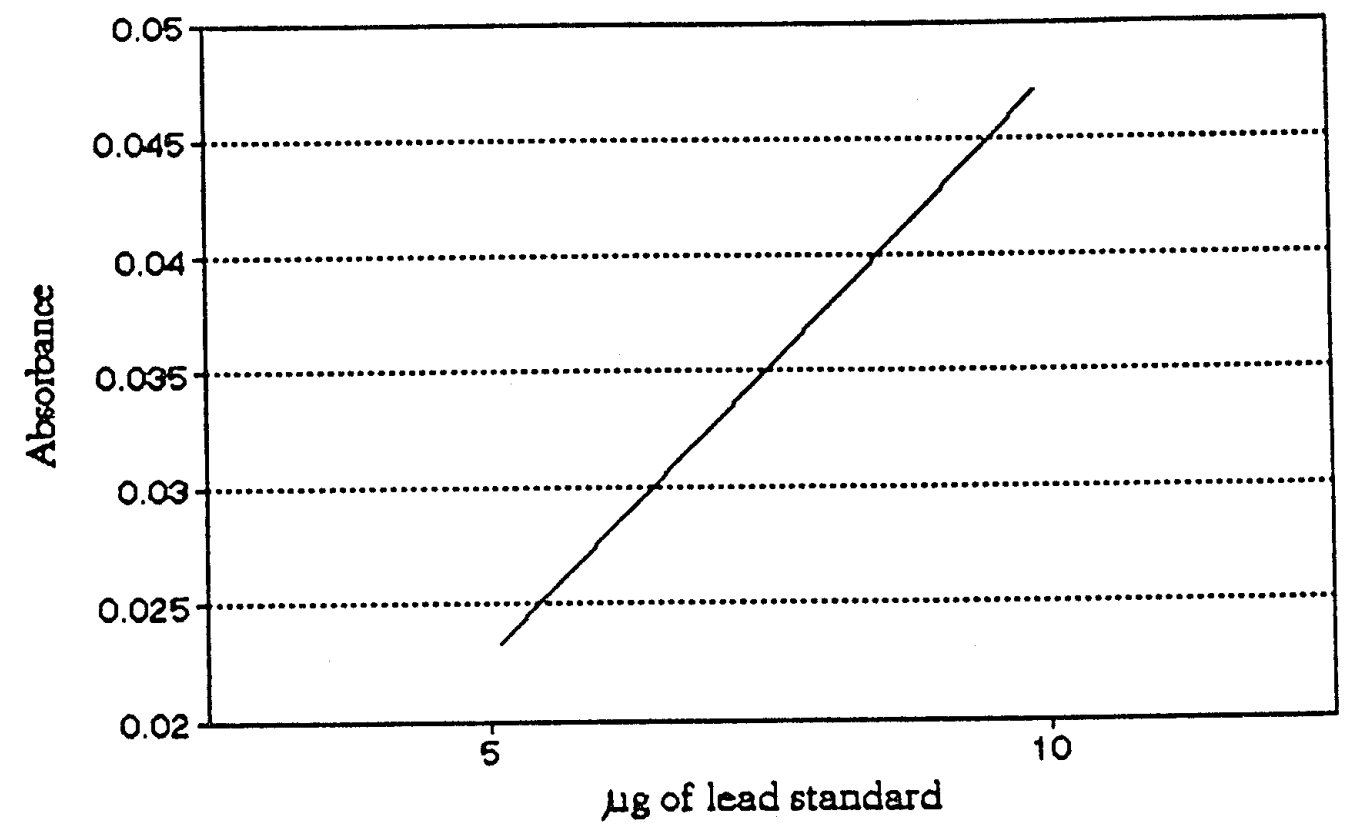

Fig. 20.--Lead calibration curve, 5/21/92 PM

2. Sample Analysis

Sample ID $10 / 29 / 91 \mathrm{MI}$

$10 / 26 / 91 \mathrm{~A} 1$

$12 / 7 / 9151$

$12 / 7 / 9153$

$12 / 7 / 9154$
Abs.

0.0196

0.0756

0.0657

0.1151

0.0462
4.35

15.73

13.72

23.76

9.76 $<\frac{\mu \mathrm{g} / \mathrm{L}}{100}$

310

270

480

200

\section{Sample Batch Three}

\section{Calibration Curve, 9/2/92}

The third batch was analyzed on $9 / 2 / 92$. Absorbance

data is listed as below in the same manner as in batch one. The best-fit calibration curve is shown in Fig. 21 . 


\begin{tabular}{rllr}
$\frac{\mu \mathrm{g}}{0.0}$ & Abs. & \multicolumn{2}{l}{ Regression Output } \\
5.0 & 0.0000 & Y-intercept & 0.0006 \\
10.0 & 0.0065 & Std Err of Y Est 0.00148 \\
20.0 & 0.0150 & R Squared & 0.98749 \\
& 0.0250 & No. of Observations & 4 \\
& & Degree of Freedom 0.00126 \\
& & Slope & Std Err of Slope 0.00001
\end{tabular}

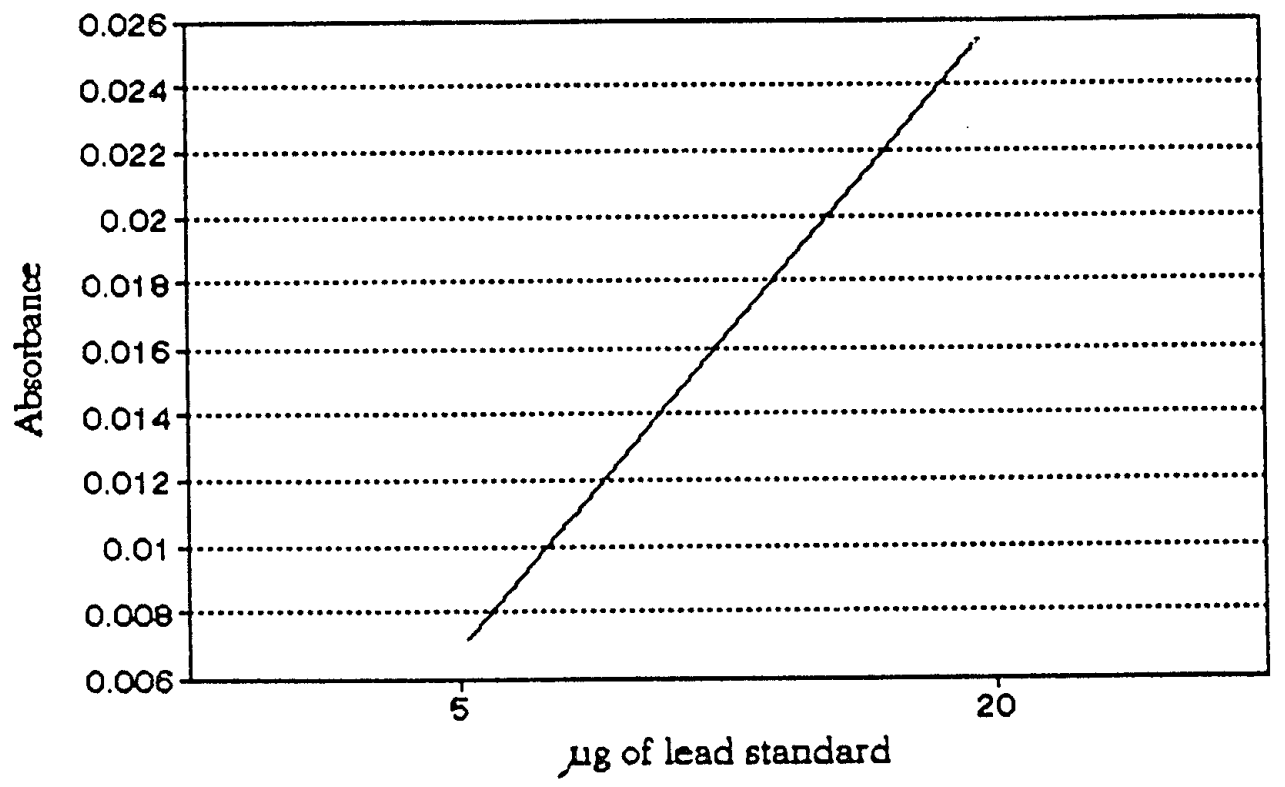

Fig. 21.--Iead calibration curve, 9/2/92

\begin{tabular}{|c|c|c|c|}
\hline $\begin{array}{l}\text { Sample ID } \\
12 / 7 / 91 \mathrm{M} 1 \\
12 / 7 / 91 \mathrm{~A} 4 \\
12 / 28 / 91 \mathrm{~S} 1 \\
12 / 28 / 9153(1) \\
12 / 28 / 9153(2) \\
12 / 28 / 9154\end{array}$ & $\begin{array}{l}\text { Abs. } \\
0.0036 \\
0.0240 \\
0.0270 \\
0.0243 \\
0.0255 \\
0.0178\end{array}$ & $\begin{array}{l}\frac{\mu \mathrm{g}}{2.38} \\
18.57 \\
20.95 \\
18.81 \\
19.76 \\
13.65\end{array}$ & $\begin{array}{r}<\mu / L \\
<100 \\
370 \\
420 \\
380 \\
400 \\
270\end{array}$ \\
\hline
\end{tabular}

\section{Sample Batch Four}

1. Calibration curve, $9 / 17 / 92$

The fourth batch was analyzed on 9/17/92. Absorbance data is listed as below in the same manner as in batch one. The best-fit calibration curve is shown in Fig. 22 . 


$\begin{array}{rl}\frac{\mu \mathrm{g}}{0.0} & \mathrm{Abs} . \\ 5.0 & 0.0000 \\ 10.0 & 0.0082 \\ 20.0 & 0.0188 \\ & 0.0352\end{array}$

Rearession Output: Y-intercept $\quad-0.0039$ Std Err of Y Est 0.00304 $R$ Squared 0.97998 No. of Observations 4 Degree of Freedom 2 Slope 0.00204 Std Err of slope 0.00021

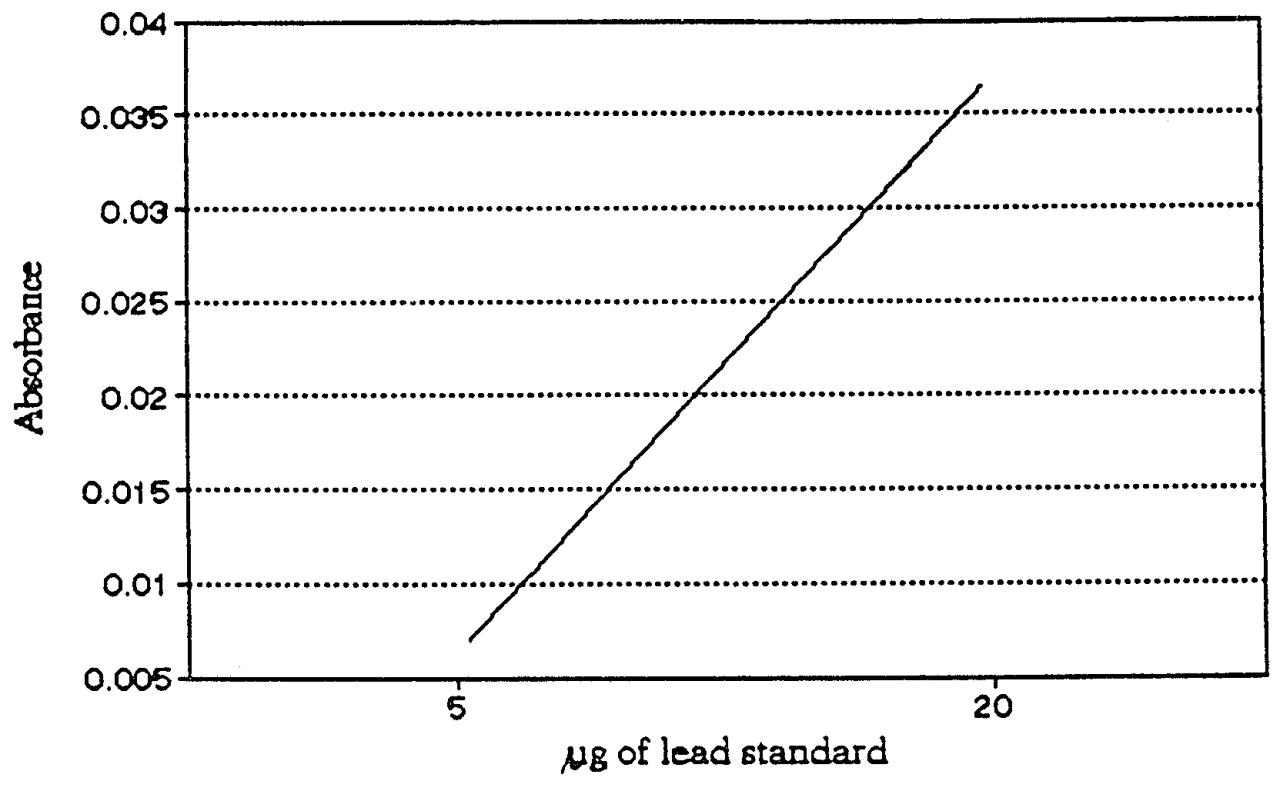

Fig. 22.--Lead calibration curve, 9/17/92

2. Sample analysis

Sample ID
10/26/91A4
$10 / 26 / 91 \mathrm{~S} 1(1)$
$10 / 26 / 91 \mathrm{~S} 1(2)$
$90810 / 26 / 91+10 \mu \mathrm{g}$
$10 / 26 / 91 \mathrm{~S} 3$
$12 / 7 / 91 \mathrm{~A} 1$
$12 / 28 / 1 \mathrm{M} 1$
$12 / 28 / 91 \mathrm{~A} 1$
$12 / 28 / 91 \mathrm{~A} 4(1)$
$12 / 28 / 91 \mathrm{A4}(2)$
$12 / 29 / 91 \mathrm{M} 1$
$12 / 29 / 91 \mathrm{~A} 1$
$12 / 29 / 91 \mathrm{~A} 4$
$12 / 29 / 91 \mathrm{~S} 1$
$12 / 29 / 91 \mathrm{S3}$
$12 / 29 / 91 \mathrm{~S} 4$

\begin{tabular}{l} 
Abs. \\
\hline 0.0156 \\
0.0228 \\
0.0218 \\
0.0454 \\
0.0256 \\
0.0517 \\
0.0152 \\
0.0140 \\
0.0085 \\
0.0075 \\
0.0064 \\
0.0103 \\
-0.0017 \\
0.0077 \\
-0.0007 \\
0.0167
\end{tabular}

pg
9.57
13.11
12.62
24.20
14.48
27.30
9.38
8.79
6.09
5.60
5.06
6.97
1.08
5.69
1.57
10.11

$\frac{\mu \mathrm{g} / \mathrm{L}}{190}$

260

250

480

290

540

190

180

120

110

100

140

$<100$

110

$<100$ 


\section{Sample Batch Five}

1. Calibration Curve, 10/1/92

The fifth batch was analyzed on $10 / 1 / 92$. Absorbance data is listed as below in the same manner as in batch one. The best-fit calibration curve is shown in Fig. 23 .

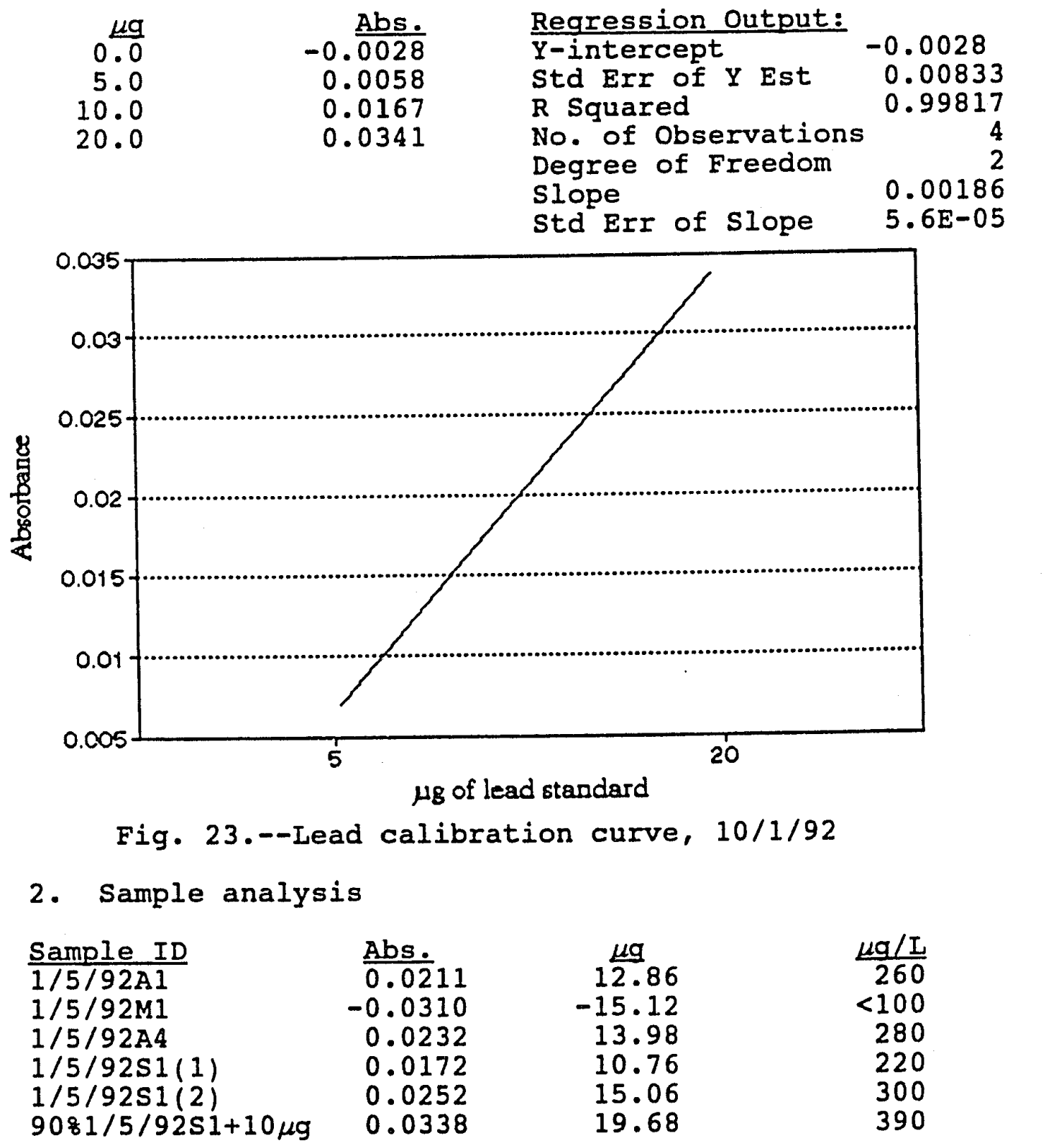


Sample ID $1 / 5 / 92531$ $1 / 5 / 92 S 4$

$2 / 15 / 92 \mathrm{~A} 1$

$2 / 15 / 92 M 1$

2/15/92A4

$2 / 15 / 9251$

$2 / 15 / 9253$

$2 / 15 / 9254$
$\frac{\mathrm{Abs} .}{0.0106}$

0.0137

0.0337

0.0374

0.0204

0.0146

0.0034

0.0188 $\mu \mathrm{g}$

7.22

8.88

19.62

21.61

12.48

9.37

3.35

11.62 $\mu \mathrm{g} / \mathrm{L}$

140

180

390

430

250

190

$<100$

230 


\author{
Appendix VI \\ EVALUATION OF DATA MEASUREMENT QUALITY
}

The measurement quality of data is evaluated in terms of precision and accuracy. Optimum evaluation requires that random samples are sent to different laboratories, preferably three, to check for the same parameters. The results are then compared for accuracy. It was beyond the financial capacity of the author to send out any samples for external checks, but for each batch internal quality control was carried out as described below.

\title{
Precision
}

Precision refers to the reproducibility of a method when it is repeated on a homogeneous sample and can be expressed by the standard deviation of $n$ observations. Range, the difference between the smallest and the largest of $n$ observations, is closely related to standard deviation. By applying a factor from a standard statistic table, range can be conveniently used to detect faulty technique, large sampling errors, or other assignable causes of variation. Equation 3 shows the calculation of range: 
where $R$ is the range, Max is the largest value and Min is the smallest value.

The precision data for the copper procedure was calculated as follows:

Sample ID $\frac{10 / 26 / 91 M 1(1)}{10 / 26 / 91 M 1(2)}$ $10 / 26 / 91 M 1(2)$

$1 / 5 / 92 \mathrm{Al}(1)$ $1 / 5 / 92 \mathrm{Al}(2)$

$$
\begin{array}{r}
\mu \underline{\mu g} \\
3.45 \\
2.89
\end{array}
$$$$
0.36
$$$$
0.09
$$

Average, $\mu \mathrm{g}$

3.16

$\mathrm{N} / \mathrm{A}$
Precision Range

0.6

$\mathrm{N} / \mathrm{A}$

It should be noted that the second set was irrelevant due to the fact that the concentration of the sample was below the calibration limit.

The precision data for the lead procedure was

\begin{tabular}{|c|c|c|c|}
\hline $\begin{array}{l}\text { Sample ID } \\
10 / 28 / 9153(1) \\
10 / 28 / 9153(2)\end{array}$ & $\begin{array}{l}18 . \frac{\mu g}{81} \\
19.76\end{array}$ & $\begin{array}{r}\text { Average, } \mathrm{kg} \\
19.28\end{array}$ & $\begin{array}{r}\text { Precision Range } \\
1.0\end{array}$ \\
\hline $\begin{array}{l}10 / 26 / 9151(1) \\
10 / 26 / 9151(2)\end{array}$ & $\begin{array}{l}13.11 \\
12.62\end{array}$ & 12.86 & 0.5 \\
\hline $\begin{array}{l}1 / 5 / 92 S 1(1) \\
1 / 5 / 92 S 1(2)\end{array}$ & $\begin{array}{l}10.76 \\
15.06\end{array}$ & 12.91 & 4.3 \\
\hline $\begin{array}{l}12 / 28 / 91 A 4(1) \\
12 / 28 / 91 A 4(2)\end{array}$ & $\begin{array}{l}6.09 \\
5.60\end{array}$ & 5.84 & 0.5 \\
\hline
\end{tabular}
calculated as follows: 


\section{Accuracy}

Accuracy refers to the agreement between the amount of a component measured by the test method and the amount actually present. Expressed in percent recovery (oR), the method of standard addition allows a known amount of standard solution to spike a sample to determine how much of the known value can be recovered. Equation 4 shows the calculation of $8 R$ :

$$
8 R=\frac{A-E}{S} \times 100
$$

where $A$ is the actual experimental value obtained from the spiked sample, $E$ is the expected value from the non-spiked sample and $S$ is the amount of standard solution added.

The accuracy data for the copper procedure was calculated as follows:

$\begin{array}{lrrr}\text { Sample ID } & \text { Expected, } \mu \mathrm{g} & \frac{8 R}{89} \\ 70810 / 26 / 91 \mathrm{MI}+10 \mu \mathrm{g} & \frac{\text { Actual, } \mu \mathrm{g}}{11.14} & <2.21 & \mathrm{~N} / \mathrm{A}\end{array}$

It should be noted that the second set was irrelevant due to the fact that the concentration of the sample was below the calibration limit.

The accuracy data for the lead procedure was calculated as follows: 
Sample ID

$70810 / 26 / 91 \mathrm{M4}+10 \mu \mathrm{g}$

$90810 / 26 / 9151+10 \mu g$

$9081 / 5 / 9251+10 \mu \mathrm{g}$

Actual, $\mu \mathrm{g}$
$\begin{array}{r}14.19 \\ 24.20 \\ 19.68\end{array}$

Expected, $\mu \mathrm{q}$
6.58
11.58
11.61

$\frac{8 R}{81}$

81

126

81

\section{Measurement Quality Conclusion}

The range of the copper procedure was 0.6 with a percent recovery of 89 . As discussed earlier, this laboratory procedure was quite straight forward. As a result, both precision and accuracy were acceptable.

The ranges of the lead procedure varied from 0.5 to 4.3 with percent recoveries from 81 to 126 . The wider range of both precision and accuracy indicated that this procedure involved more variables such as exactness of extraction time and shaking movement, moisture interference in the organic layer, instability of the color, etc. 


\section{BIBLIOGRAPHY}

Bliar, David, Harvey Diehl, "Bathophenanthrolinedisulphonic Acid and Bathocuproinedisulphonic Acid, Water Soluble Reagents for Iron and Copper," Talanta, 1961, vol. 7.

Callahan, Michael A., Michael w. Slimak, Norman W. Gabel, et al. Water-Related Environmental Fate of 129 Priority Pollutants, Vol 1 , Introduction, and Technical Background, Metals and Inorganics, Pesticides and PCBs. Office of Water Planning and Standard, Office of Water and Waste Management, US Environmental Protection Agency, Washington, D.C., 1979.

City of Palo Alto, 1984-Major Street Traffic Flow, 24 Hour Counts, Office of the Traffic Engineer, City of Palo Alto, $\mathrm{Ca}$.

City of Palo Alto, ITT Marsh Enhancement Project, Annual Report, 1992.

City of Palo Alto, Industrial Waste Laboratory Report, 1992.

Cowardin, I. M., V. Carter, F. C. Golet, and E. T. LaRoe, Classification of Wetlands And Deepwater Habitats of the United States. US Department of Interior, 1979.

Greenberg, Arnold E., Joseph J. Connors, David Jenkins, ed., Standard Methods for the Examination of Water and Wastewater. $15^{\text {th }}$ edition, American Public Health Association, Washington D.C. 1980.

Griffin, D.M., C.W. Randall and T.J. Grizzard, "Efficient Design of Stormwater Holding Basins Used for Water Quality Protection," Water Research, 14, Elmsford, N.Y.:Pergamon Press, 1980 .

Hornor, Edith R., editor, California Cities, Towns and Countries, Basic Data Profiles for all Municipalies and Counties, 1992. Information publication, Palo Alto, Ca.

Livington, Eric H., "Use of Wetlands for Urban Stormwater Management," Donald A. Hammer, Ed., Constructed Wetlands for Wastewater Treatment, Municipal, Industrial and Agricultural. Lewis Publishers, Inc., Michigan, 1989 . 


\section{BIBLIOGRAPHY}

Marczenko, Zygmunt, Separation and Spectrophotometric Determination of Elements. Mary Masson, translation ed., John Wiley \& Sons, New York, 1960.

Meiorin, Emy Chen, Urban Stormwater Treatment at Coyote Hills Marsh, Final Report. Association of Bay Area Governments, Oakland Ca., 1986.

National Weather service, Official Weather Observer's Record at Palo Alto Fire Station. National Oceanic and Atmospheric Administration, us Department of Commerce, 1991 and 1992

Randall, C.W. Occoquan/ Four Mile Run Nonpoint Source Correlation Study -- Final Report, Northern Virginia Planning District Commission and Virginia Polytechnic Institute and State University, 1978.

Steiner, Gerald R. and Rebert J. Freeman, Jr., "Configuration and Substrate design Considerations for Constructed Wetlands Wastewater Treatment," Donald A. Hammer, ed., Constructed Wetlands for Wastewater Treatment, Municipal, Industrial and Agricultural, Lewis Publishers, Inc., Michigan, 1989.

Woodward-Clyde Consultants, Interim Draft Final Two Year Report for Palo Alto NPDES Special study Requirements, Oakland, Ca., 1991. 